Pegem Journal of Education \& Instruction, 4(1), 2014, 01-26

Pegem Eğitim ve Öğretim Dergisi, 4(1), 2014, 01-26

www.pegegog.net

\title{
Opinions of Teachers About Orientation and Preparation Activities
}

\section{Aslı GÜNDOĞAN ÇÖGENLi ${ }^{\mathrm{a}^{*}}$, Aybüke UÇANSOY ${ }^{b}$}

${ }^{a}$ Uşak University, Faculty of Education, Uşak/Turkey

${ }^{\mathrm{b}}$ Dumlupınar University,Faculty of Education, Kütahya/Turkey

\section{Article Info}

DOI: $10.14527 /$ pegegog.2014.001

Article history:

Received 24 May 2013

Revised 16 December 2013

Accepted 29 December 2013

Keywords:

Orientation and preparation

activities,

Teachers' opinions.

\begin{abstract}
The main purpose of this study is to determine the teachers' opinions about orientation and preparation activities. The data of the study in which qualitative research method is used is confined by semi-structure interview with ten primary school teachers. In the process of analyzing the data, description-analyze method has been used. In the research, some themes including activity, time, student, preparing for other courses, teacher, parents and suggestions have been reached. Sub-themes and codes belonging to the each theme have been identified and some example views are taken place by quoting from teachers to explain the codes which are identified. As a result of the research, teachers notified that activities are simple and also inadequate for preparing students for the other lessons and time is inadequate and unplanned as well, and they also emphasized that the activities are difficult for students, and finally, due to their class-roles, teachers commented that they have some difficulties on class-management and they also commented on some different attitudes of parents.
\end{abstract}

\section{Introduction}

In 2012, Turkey witnessed a fundamental change in Turkish Education System with the introduction of a Gradual Mandatory Education System named "4+4+4 Model". The starting age has been reduced to 5 years, which in turn brought the issue of earlier literacy training to the agenda. With this amendment, a directive called "Orientation and preparation activities" has been issued by the Board of Education Directorate at the Ministry of National Education. The directive covers some activities which are designed for students who started school in 2012-2013 school year and who are at least 60 months old. These activities are to be carried out in the first three months in first grade at primary schools.

Orientation and preparation activities aim to facilitate the orientation of new students to the school, to their friends, teachers and teaching practices; and to establish a sound base for literacy training through preparatory practices targeting first year courses, and to consider attainments in introduction to Science, Mathematics, Visual Arts, Music, Physical Activities and Games courses to a certain extent (MEB, 2012).

Many students first meet social life at their first year in school and their experiences in this year form the grounds on which they structure their lives. Stating the primary school is an important milestone in a child's life. The child, starting the first grade in primary school, is faced for the first time with some duties such as participating in events and activities required within programmed training, obeying some rules in a specific disciplined way, adhering to teacher's instructions and last but not least, learning such subjects as arithmetic, reading and literacy (Erkan \& Kırca, 2010). The first grade is of great importance both for the student and for the teacher. In this period, teachers have a significant role as fundamental

*Corresponding author: agcogenli@hotmail.com 
players within the education system. The introduction of gradual compulsory education system practices have multiplied teachers' responsibilities and required teachers to revise their previous teaching practices. In this vein, the need for the identification of the first year experiences by teachers, activities they conduct, the difficulties they face in orientation and preparation activities has become prominent.

The main purpose of this study is to determine the teachers' opinions about orientation and preparation activities. Research questions are as follows:

- What are the general opinions of teachers on orientation and preparation activities?

- What do the teachers think about their students?

- What do the teachers think about the preparation of students for other courses through orientation and preparation activities?

- What are the teacher roles in the scope of orientation and preparation activities?

- What are the teachers' observations regarding the first graders' parents?

- What are the suggestions for studies by teachers?

\section{Method}

\section{Research Design}

The current research is based on a qualitative approach. Qualitative research can be defined as a study design which follows a qualitative path directed at realistic and holistic disclosure of the perceptions and events in their natural settings through qualitative data collection methods such as observation, interview and document analysis (Yıldırım \& Şimşek, 2011).

\section{Participants}

In qualitatively patterned studies, the participants are identified through a purposeful sampling procedure (Creswell, 2005). Among the purposeful sampling procedures, criterion based sampling is selected for the current study. In criterion sampling procedure, the entities who meet the predetermined criteria are included in the sample (Büyüköztürk, Kılıç Çakmak, Akgün, Karadeniz \& Demirel, 2012). The selection of the participants is based on two criteria; these are voluntary participation and being a teacher at first grade in a primary school.

\section{Instrument}

Semi-structured interview form is used as the data collection instrument. Interview questions are determined in accordance with the sub-aims of the study and are negotiated with three field experts to ensure validity of the scope. In the light of the feedback received from the experts, the interview questions are piloted with 2 first grade teachers. The voice recordings of the pilot interviews have been analyzed and questions are revised for data collection.

\section{Data Analysis}

The data have been gathered from 10 teachers who taught first graders in 2012-2013 Fall term. Teachers have been asked 9 questions and the interviews have been audio-recorded. The data have been descriptively analyzed. In descriptive analysis, the questions included in data collection instruments such as observation, interview and documenting are taken as the grounds for the analysis (Ekiz, 2009). In the descriptive analysis phase employed in this study, the voice recordings have been transcribed. The transcribed data have been transferred into the detailed interview form. Upon completing the transfer of transcribed data to detailed interview forms and the required coding procedure, data have been matched. In this phase, codes have been integrated and emerging subthemes have been incorporated under the main themes. Moreover, some other procedures are 
employed to ensure credibility. In this respect, an expert has supported in the data analysis and the findings have been evaluated by an outsider expert as well (Büyüköztürk, Kılıç Çakmak, Akgün, Karadeniz \& Demirel, 2012).

\section{Results}

According to research results, some themes including activity, time, student, preparation for other courses, teacher, parents and suggestions have been reached. The themes "Activity" and "Time" have been established with respect to the question "What are the general opinions of teachers on orientation and preparation activities?". The theme "Student" is defined for "What do the teachers think about their students?"; while the theme "Preparation for other courses" has been defined for the question "What do the teachers think about the preparation of students for other courses through orientation and preparation activities?". "What are the teacher roles in the scope of orientation and preparation activities?" have brought the theme "Teacher"; and the question "What are the teachers' observations regarding the first graders' parents?" put forward the theme "Parents". Finally, "Suggestions" theme is filled by responses to "What are the suggestions for studies by teachers?".

\section{Discussion, Conclusion \& Implementation}

The teachers who provided data for the "Activity" theme noted that the sequencing of activities across the weeks does not follow a difficulty order and that there is no gradual increase in the difficulty degrees of the activities. In the sequencing of the content, among the fundamental principles are to follow an order from the concrete to the abstract, simple to complex, easy to hard; from whole to the part or from part to the whole, from current to past, from events to concepts and generalizations and from immediate to distant environment (Demirel, 2007). In this respect, a systematic approach cannot be claimed to exist in the sequencing of content in orientation and preparation activities.

Under the theme "Time", teachers comment that they will cover the subjects faster or that they might allocate other course hours to cover all the content. It has been observed that teachers have difficulty in managing class time. Teacher should be able to use class time efficiently to ensure an effective training (Ekici, 2009, p.101). The whole class time should be allocated for educational purposes; therefore, classroom procedures should be carefully planned and timed (Basar, 1999). Eliminating the loss of class-time might not be possible; however, teachers should at least try to minimize the time lost during the classes (Aksut, 2008). This demonstrates the necessity that first grade teachers should make more efforts to use class-time effectively.

The teachers who commented on "Student" theme have mentioned the cognitive, affective and psycho-motor difficulties faced by students. For cognitive difficulties, teachers noted that younger students have trouble in conforming to teacher instructions. For affective difficulties, teachers told that younger children feel themselves incompetent when compared to older ones and thus experience emotional breakdowns. Bilir (2005) states that it is not only inefficient to teach something to a child who is not yet ready to learn, but it also leads the child to feelings of failure, disappointment and inferiority. About the psycho-motor difficulties, teachers mentioned that younger children have not yet completed their muscular development. The larger muscle development is more advanced than smaller muscle development in the children at this age group; therefore, the children are competent in larger muscle skills such as running, jumping and climbing but less competent in smaller muscle skills such as writing, drawing, using scissors and so on (Senemoglu, 2005). According to Dereli (2012), a successful transition to primary education might be possible through readiness; which can be ensured by bringing the child to a level that is appropriate for primary education in terms of emotional, psychological, physical and mental development. While talking about the level differences stemming from the differences in children's age groups, teachers observed that younger children start the activities with eagerness while older students get bored. At this point, teacher should provide effective classroom management. 
Effective classroom management requires teachers to know students' interests, expectations and necessities (Aydın, 2000, p. 16). Some teachers who talked about 60-months-old students in their class reported that they face student characteristics to which they are not accustomed. Students who are not yet sufficiently developed and mature might be deprived of the energy they need in educational activities. This may hinder their academic performance and might cause them to have feelings of failure (Bilgin, 2009). Education and school period is an important phase in which many adaptation problems might arise in the child's life (Topses, 2007, p. 23). In the first days at school, teacher should take precautions to facilitate the adaptation of children to the school life. Readiness levels have an important role at the start of primary education. In different countries around the world, the studies on whether the children are mentally and social mature enough to meet the responsibilities introduced by the schools have been conducted for many years. In many countries, readiness level tests are employed before children start going to school and the multilateral maturity of the child is considered important (Kutluca Canbulat \& Canbulat, 2012). Some studies are needed in our country as well, to understand whether the children at the school age are really ready to go to school.

Teachers mentioned preparation to Mathematics, Life Sciences and literacy skills when talking under the theme "Preparation for other courses". Teachers noted that some students have difficulty in implicit arithmetic tasks in Mathematics courses. They also noted that intuitional activities to teach sounds in literacy lessons are very abstract for the young students. Children at preoperational phase have difficulty in understanding the conservation of matter, and they cannot understand abstract concepts, either. For instance, the immobile objects are "dead" for them; and they are "alive" when they move (Erden \& Akman, 1995, p. 57). Teachers state that students see the activities as games and therefore they like doing these. According to Bilir (2005), children at primary school age have a great need for moving and playing. When the teacher opinions on preparation to Life Sciences course are considered, it can be seen that the teachers think the content of the Life Sciences course-book consists of simple and widely known subjects; and therefore, they emphasize that it can be learnt without the book. Dundar (2002) states that, with this course, students acquire basic knowledge on nature and societal life and they gain intellectual skills necessary for them to use in their daily life and to adapt to new situations.

When talking about the theme "Teacher", teachers said that they have difficulty in classroom management. Teachers note that they feel themselves as pre-school teachers during the adaptation period. For teachers to perform their profession as required, they need to have received sufficient and qualified pre-service and in-service training (Gurkan, 2013). National Education Basic Law, numbered 1739 , states that teacher preparation is provided through world knowledge, subject specific training and pedagogical formation (National Education Basic Law, 1973); and higher education institutions for educating teachers have aimed to equip teachers with specific qualities through courses in the previously mentioned areas. It can be observed that in pre-school and primary school teacher education programs, world knowledge and teaching profession knowledge courses are similar while subject specific courses differ. To eliminate this problem, the amendments should be done either to redefine age groups at primary schools or to include courses, which will help teachers respond to 60-month-old children's needs, in primary teacher education programs at higher education.

Teacher comments in terms of "Parents" indicate that some younger children's parents are anxious, some parents are neglecting, some are concerned while some accuse the teachers or students for failure. The parents should refrain from behaviors which might lead to school anxiety in children and should provide their children with unprejudiced and realistic information about their school. They should be as calm as possible during the first days at school, and should not reflect their anxiety on their child (Yasar, 2013).

Teachers have provided suggestions for practice, time, students and teachers under the theme of "Suggestions" as well. 
Pegem Journal of Education \& Instruction, 4(1), 2014, 01-26

Pegem Eğitim ve Öğretim Dergisi, 4(1), 2014, 01-26

www.pegegog.net

\section{Sınıf Öğretmenlerinin Uyum ve Hazırlık Çalışmalarına Illişkin Görüşleri}

\section{Aslı GÜNDOĞAN ÇÖGENLi ${ }^{a^{*}}$, Aybüke UÇANSOY ${ }^{b}$}

${ }^{a}$ Uşak Üniversitesi, Eğitim Fakültesi, Uşak/Türkiye

${ }^{\mathrm{b}}$ Dumlupınar Üniversitesi, Eğitim Fakültesi, Kütahya/Türkiye

\section{Makale Bilgisi}

DOI: 10.14527/pegegog.2014.001

Makale geçmişi:

Düzeltme 16 Aralık2013

Kabul 29 Aralık2013

Anahtar kelimeler:

Öğretmen görüşleri.
Geliş 24 Mayıs 2013

Uyum ve hazırlık çalışmaları,

\section{Öz}

Bu çalışmada, uyum ve hazırlık çalışmalarına ilişkin öğretmen görüşlerinin belirlenmesi amaçlanmışır. Nitel araştırma deseninin benimsendiği araştırmada veriler, 10 birinci sınıf öğretmeninden yarı yapılandırılmış görüşmeler yoluyla toplanmıştı. Verilerin analizinde betimsel analiz yöntemi kullanılmıştır. Araştırmada, araştırma sorularına dayalı olarak etkinlik, süre, öğrenci, diğer derslere hazırlama, öğretmen, veli ve öneriler olmak üzere yedi tema oluşturulmuş; her temaya ilişkin alt temalar ve kodlar belirlenmiş ve kodlar açıklanırken öğretmenlerden alıntılar yapılarak örnek görüşlere yer verilmiştir. Araştırma sonuçlarına dayalı olarak öğretmenler etkinlikleri basit bulduklarına, sürenin yetersiz ve plansız olduğuna, öğrencilerin sıkıntılar yaşadıklarına, çalışmaların öğrencileri diğer derslere hazırlamada çok fazla etkili olmadığına, kendi rollerine ilişkin olarak sınıf yönetimini sağlamada zorluk çektiklerine ve velilerin farkı tutumlarına ilişkin görüş bildirmişlerdir.

Giriş

Türkiye'de 2012 yılında "4+4+4" olarak adlandırılan Kademeli Zorunlu Eğitim Sistemi ile Türk Eğitim Sistemi'nde köklü değişiklikler yapılmıştır. Bu köklü değişiklikler kapsamında okula başlama yaşı 5’e düşürülmüş; bu durum öğrencilerin daha erken yaşta okuma-yazma öğrenmesini gündeme getirmiştir. Bu değişiklik kapsamında, Milli Eğitim Bakanlığı Talim Terbiye Kurulu Başkanlığı tarafından "Uyum ve Hazırlık Çalışmaları" adında bir yönerge uygulamaya koyulmuştur. Yönerge, 2012-2013 öğretim yılından itibaren okula başlayan ve 60 ayını doldurmuş öğrencilere yönelik, okullarda ilk 3 ayda gerçekleştirilmesi gereken etkinlikleri kapsamaktadır.

Uyum ve hazırlık çalışmalarının amacı, ilkokula yeni başlayan öğrencilerin okula, arkadaşlarına, öğretmenlerine, öğretim etkinliklerine uyumunu kolaylaştırmak; birinci sınıf derslerine hazırlık çalışmaları yaparak okuma-yazma çalışmalarına temel oluşturmak ve Hayat Bilgisi, Matematik, Görsel Sanatlar, Müzik, Oyun ve Fiziki Etkinlikler derslerindeki kazanımları belli oranda ele almaktır. Buna göre Türkçe dersinde, uyum ve hazırlık çalışmaları süresince, "görsel okuma, dinleme, sesleri tanıma, ses benzerliği, iletişim kurma, görsel algının geliştirilmesi, dikkat becerilerinin geliştirilmesi, ses farkındalığı ve yazı bilincinin oluşturulması ve çizgi çalışmaları gibi becerilerin yapılandırılması" amaçlanmıştır. Hayat Bilgisi dersinde, genel olarak sınıfına ve okuluna uyum; kendini, arkadaşlarını ve okulunu tanıma; sınıf ve okul kurallarını öğrenme; öz bakım becerilerini edinme, değerlerimizi tanıma; günlük yaşam becerilerin yanı sıra, araştırma ve yeni şeyler öğrenme isteğinin kazandırılması gibi becerilerin edinimi hedeflenmiştir. Matematik dersi kapsamında, öğrencilerin muhakeme yapma ve problem çözme becerilerini geliştirmek amacıyla sıraya koyma, kıyaslama, hatırlama, eşleştirme, sayıları günlük hayatta kullanma, basit ölçme çalışmaları yapma, nesneleri gruplama, örüntü tamamlama, görsel algıyı destekleme gibi çalışmalar yer almaktadır. Oyun ve Fiziki Etkinlikler, Müzik ve Görsel Sanatlar dersleri kapsamında tasarlanan etkinliklerle ise küçük ve büyük kasların geliştirilmesi, el göz koordinasyonu,

*Yazar: agcogenli@hotmail.com 
dikkat becerilerinin geliştirilmesi, renklerin uyumu ve yaratıcılık, sesleri tanıma, ritmi tanıma ve ritim tutma gibi becerilerin tümünün oyun, fiziksel ve zihinsel etkinliklerle geliştirilmesi hedeflenmiştir (MEB, 2012). Tüm bu derslerin içeriğine bakıldığında, etkinliklerin okul öncesi ile ilkokul birinci sınıf öğretim programlarının kesişim noktası olduğunu söylemek mümkündür.

Çoğu öğrencinin sosyal yaşamla tanışması, ilkokul birinci sınıfta gerçekleşir ve bu dönemde edindikleri deneyimler, yaşamlarını yapılandırmalarına temel oluşturur. Bu bağlamda ilkokula başlamak çocuğun yaşamında önemli bir yere sahiptir. Birinci sınıfa başlayan bir çocuk ilk kez programlı öğretimin gerektirdiği etkinliklere katılmak, belirli bir disiplin içinde kurallara uymak, öğretmenin talimatını yerine getirmek ve en önemlisi okuma-yazma, aritmetik ve benzeri konuları öğrenme gibi görevlerle karşı karşıyadır (Erkan ve Kırca, 2010). Dolayısıyla birinci sınıf, hem öğrenci hem de öğretmen için büyük bir öneme sahiptir. Bu süreçte, eğitim sisteminin temel bileşenlerinden olan öğretmenlere büyük görevler düşmektedir. Bu nedenle kademeli zorunlu eğitim sistemine geçiş, öğretmenlerin sorumluluğunu arttırmış; daha önce sürdürdükleri uygulamaları değiştirmelerini gerektirmiştir. Buna dayalı olarak öğretmenlerin uyum ve hazırlık çalışmaları kapsamındaki ilk yıl deneyimlerinin, gerçekleştikleri uygulamaların ve bu süreçte karşılaştıkları güçlüklerin belirlenmesi gereksinimi doğmuştur. Eğitim sistemlerinin en önemli öğelerinden olan eğitim programlarının uygulanmasında en önemli rol, kuşkusuz ki öğretmenlere düşmektedir. Öğretmenlerin uyguladıkları program hakkındaki görüşlerinin belirlenmesi, o programa ilişkin eksik ve zayıf yönlerin ortaya çıkmasını sağlayarak, ilgililerin programı yeniden gözden geçirmelerine imkân sağlayacaktır. Bu araştırma, söz konusu gereksinimlerden yola çıkılarak desenlenmiştir.

$\mathrm{Bu}$ araştırmanın amacı, sınıf öğretmenlerinin uyum ve hazırlık çalışmalarına ilişkin görüşlerini belirlemektir. Bu genel amaç doğrultusunda araştırmada şu sorulara yanıt aranmıştır:

- Öğretmenlerin uyum ve hazırlık çalışmaları hakkındaki genel düşünceleri nelerdir? o Etkinliklere ilişkin düşünceleri nelerdir?

o Süreye ilişkin düşünceleri nelerdir?

- Öğretmenlerin uyum ve hazırlık çalışmaları kapsamında, öğrencilere ilişkin düşünceleri nelerdir?

- Öğretmenlerin uyum ve hazırlık çalışmalarının öğrencileri diğer derslere hazırlamasına ilişkin düşünceleri nelerdir?

- Uyum ve hazırlık çalışmaları kapsamında öğretmenlerin rolleri nelerdir?

- Öğretmenlerin birinci sınıf öğrenci velilerine ilişkin gözlemleri nelerdir?

- Öğretmenlerin çalışmalara ilişkin önerileri nelerdir?

\section{Yöntem}

\section{Araştırma Modeli}

Araştırma, nitel araştırma yaklaşımıyla gerçekleştirilmiştir. Nitel araştırma, gözlem, görüşme ve doküman analizi gibi nitel veri toplama yöntemlerinin kullanıldığı, algıların ve olayların doğal ortamda gerçekçi ve bütüncül bir biçimde ortaya konmasına yönelik nitel bir sürecin izlendiği araştırma olarak açıklanır (Yıldırım ve Şimşek, 2011).

\section{Katılımcılar}

Nitel olarak desenlenen araştırmalarda katılımcılar, amaçlı örnekleme yöntemi ile belirlenir (Creswell, 2005). Araştırmada amaçlı örnekleme yöntemlerinden ölçüt örnekleme yöntemi benimsenmiştir. Ölçüt örneklemede örneklem için belirlenen ölçütü karşılayan birimler (nesneler, olaylar, vb.) örnekleme alınırlar (Büyüköztürk, Kılıç Çakmak, Akgün, Karadeniz ve Demirel, 2012). Bu bağlamda katılımcıların belirlenmesinde araştırmaya gönüllü katılım ve ilkokul birinci sınıf öğretmeni olma biçiminde iki temel ölçüt dikkate alınmıştır. Araştırmaya katılan öğretmenlerin kişisel özelliklerine ilişkin bilgiler Tablo 1'de sunulmuştur. 
Tablo 1.

Öğretmenlerin Kişisel Özellikleri.

\begin{tabular}{ccc}
\hline Katılımcı & Cinsiyet & $\begin{array}{c}\text { Mesleki } \\
\text { Deneyim (Yıl) }\end{array}$ \\
\hline Ö1 & Erkek & 13 \\
Ö2 & Kadın & 24 \\
Ö3 & Kadın & 20 \\
Ö4 & Kadın & 6 \\
Ö5 & Kadın & 36 \\
Ö6 & Kadın & 25 \\
Ö7 & Kadın & 20 \\
Ö8 & Kadın & 26 \\
Ö9 & Erkek & 25 \\
Ö10 & Erkek & 18 \\
\hline
\end{tabular}

\section{Veri Toplama Aracı}

Araştırmada veri toplama aracı olarak yarı yapılandırılmış görüşme formu kullanılmıştır. Görüşme soruları, araştırmanın alt amaçlarına dayalı olarak belirlenmiş ve kapsam geçerliğinin sınanması amacıyla 3 alan uzmanına sunulmuştur. Alan uzmanları görüşme sorularını içerik ve biçim bakımından incelemiş; kimi soruları formdan çıkarmış kimi soruların da anlatım biçimlerini yeniden düzenlemiştir. Uzmanlardan gelen dönütler doğrultusunda görüşme soruları ön uygulama için 2 birinci sınıf öğretmenine uygulanmıştır. Ön uygulamadan elde edilen ses kayıtları incelenerek soruların işleyip işlemediğine bakılmış ve sorulara son biçimi verilerek uygulamaya hazır duruma getirilmiştir.

\section{Verilerin Toplanması}

Araştırma verileri 2012-2013 güz yarıyılında 1. sınıfları okutan 10 sınıf öğretmeninden, yarı yapılandırılmış görüşmeler yoluyla toplanmıştır. Öğretmenlere toplam 9 soru yöneltilmiş ve görüşmeler ses kayıt cihazı ile kayıt altına alınmıştır.

\section{Verilerin Analizi}

Toplanan veriler betimsel olarak analiz edilmiştir. Betimsel analizde, araştırmada kullanılan gözlem, görüşme ve doküman gibi veri toplama araçlarında yer alan soru, konu ya da temalar temele alınarak analiz edilir (Ekiz, 2009). Bu bağlamda görüşme soruları, temaları oluşturmuştur. Araştırmada kullanılan betimsel analiz sürecinde öncelikle ses kayıtlarının döküm işlemi gerçekleştirilmiştir. Bu sırada bir araştırmacı döküm işlemini gerçekleştirirken öteki araştırmacı da dökümün doğruluğunu kontrol etmiştir. Bu işlemleri araştırmacılar birbirinden bağımsız olarak yapmışlardır. Dökümü yapılan veriler, ayrıntılı görüşme formuna aktarılmıştır. Ayrıntılı görüşme formu, bağlamsal bilgiler (Görüşme tarihi, görüşülen kişi, görüşmeci, tarih vb), betimsel indeks, betimsel veri, görüşmeci yorumu ve genel yorum bölümleri olmak üzere beş bölümden oluşmaktadır. Bu forma dayalı olarak, betimsel veri bölümünde öğretmenlerin sorulara ilişkin ifade ettikleri görüşlerini en iyi yansıttığı düşünülen sözcük grubu betimsel indeks bölümüne yazılmıştır. Böylece kodlama işlemi gerçekleştirilmiştir. Tüm dökümler ayrıntılı görüşme formuna aktarıldıktan ve gerekli kodlama işlemleri yapıldıktan sonra verilerin eşleştirilmesi işlemine geçilmiştir. Bu işlemde kodlar birleştirilerek alt temalar oluşturulmuş ve her bir alt tema, temaların altına yerleştirilmiştir. Bu işlemi araştırmacılar birbirinden bağımsız olarak gerçekleştirmişlerdir. Daha sonra gerçekleştirilen eşleştirmeler karşılaştırılmış; görüş ayrılığı bulunan eşleştirmelere ilişkin görüş birliğine varılmıştır. Bu işlemden sonra temalar, alt temalar ve kodlar tekrar gözden geçirilmiş ve verilere son biçimi verilmiştir. Ayrıca, araştırmada inandırıcılığın sağlanması amacıyla farklı işlemler yapılmıştır. Bu bağlamda araştırma verilerinin analizinde bir uzmandan yardım alınmıştır. Yine araştırma bulguları çalışmanın dışında olan bir uzman tarafından değerlendirilmiştir 
(Büyüköztürk, Kılıç Çakmak, Akgün, Karadeniz ve Demirel, 2012). Alt temalar ve kodlar oluşturulurken öğretmen görüşleri sürekli birbiriyle karşılaştırılmıştır.

\section{Bulgular}

Bu bölümde temalar, alt temalar ve kodlar, araştırma sorularından oluşan başlıklar altında sunulmuş; kodlar açıklanırken öğretmenlerden alıntılar yapılarak örnek görüşlere yer verilmiştir. Araştırma sorularına dayalı olarak oluşturulan temalar Şekil 1'de verilmiştir.

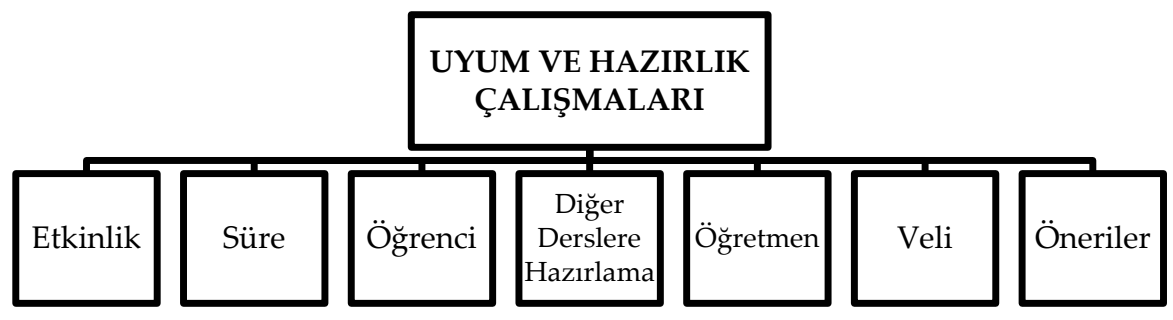

Şekil 1. Temalar.

Şekil 1'de görüldüğü gibi “Etkinlik”, "Süre”, “Öğrenci”, “Diğer derslere hazırlama”, "Öğretmen”, "Veli” ve "Öneriler" olmak üzere yedi tema oluşturulmuştur.

\section{Öğretmenlerin Uyum ve Hazırlık Çalışmaları Hakkındaki Genel Düşünceleri}

Araştırmada ilk olarak yanıt aranan "Öğretmenlerin uyum ve hazırlık çalışmaları hakkındaki genel düşünceleri nelerdir?" sorusuna yönelik olarak "Etkinlik" ve "Süre" temaları oluşturulmuştur. "Etkinlik" temasına ilişkin alt temalar ve kodlar Şekil 2'de verilmiştir.

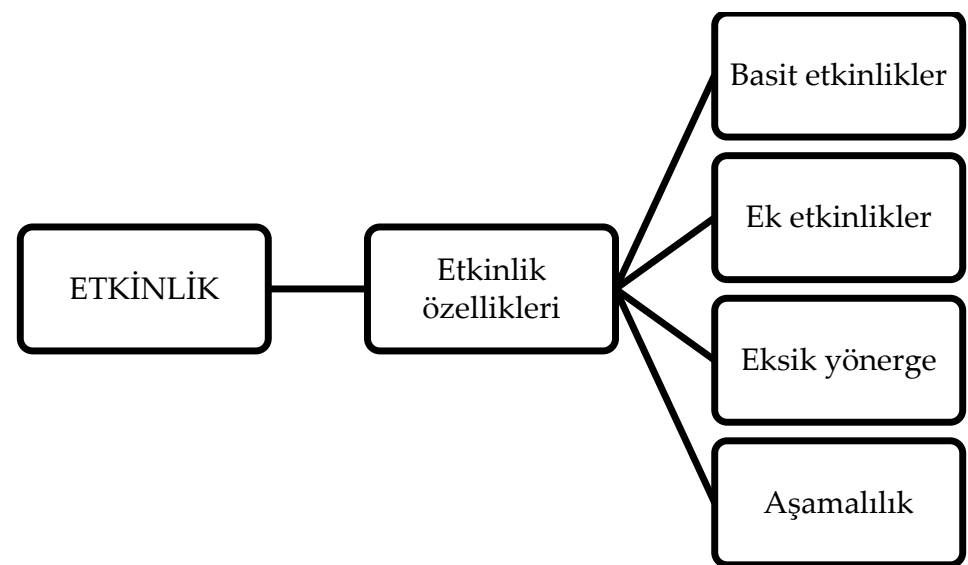

Şekil 2. "Etkinlik" Temasına ilişkin Alt Temalar ve Kodlar.

Şekil 2'de görüldüğü gibi "Etkinlik" temasını "Etkinlik özellikleri” alt teması oluşmuştur. "Etkinlik özellikleri" alt temasını oluşturan basit etkinlikler koduna ilişkin olan öğretmen görüşlerinin örnekleri aşağıda verilmiştir.

Çalışma kitabındaki etkinliklerin çoğu çok basit, yani hiç eline kalemi almamış, hiç çalışma yapmamış çocuklar için hazırlanmış. Çok basit çizgiler, çok basit çalışmalar var (Ö1).

Mesela "8" rakamını öğreten bir etkinlik vardı. Fakat çocuk zaten yirmiye kadar rakamları öğrenmiş de gelmiş. Bu çocuğa sekizin üzerinden git, ondan sonra sekiz tane noktacık boya dediğimde çocuk zaten 
onu iki dakikada yapıyor. Basit geliyor. Ondan sonra da sıkılıyor. Sıkılanlara farklı etkinlikler vermek zorunda kaldım. Sekiz rakamını çıkarttım geldim fotokopiyle dağıttım. Boyayın dedim ama boyamaktan da sıkılmışlar. Artık son zamanlarda öyle kargacık burgacık boyuyorlardı ki çocuk boyayı bildiği halde karalıyordu sadece (Ö7).

Basit etkinlikler kodunda görüş belirten öğretmenler, etkinliklerin oldukça basit olduğunu vurgulamıştır. Bu konuda görüş belirten öğretmenlerden biri (Ö7), örnek olarak verdiği etkinliğinin zaten öğrenciler tarafından bilindiğini, bildikleri şeyleri tekrar yapmak istemediklerini ve bu nedenlerle etkinlikleri basit bulduğunu anlatmıştır. "Etkinlik özellikleri" alt temasını oluşturan ek etkinlikler koduna ilişkin olan öğretmen görüşlerinin örnekleri aşağıda verilmiştir.

Uyum kitabının yanında kendimiz de ek çalışmalar verdik. Yani onunla kalsaydık çok yavaş ilerlerdik. Biz yanında ne yaptık? Ek çizgi çalışmaları verdik. Farklı şekiller, resimler verdik. Boyamalarını istedik. Yani hep destekledik (Ö6).

Etkinlikleri fotokopiyle destekledim. Yani, mesela, işte uğur böcekleri yaptım, sekiz tanesini boya, altına sekiz rakamını yaz, dedim. Ondan sonra kutucuk yaptık bunun içine sekiz yap, sekizden önce hangisi geliyor, sekizden sonra hangi rakama geçeceğiz, sizce ne var şeklinde ek etkinlikler yaptırdım. Bu şekilde fotokopiyle destekledim (Ö7).

Ek etkinlikler kodunda görüş belirten öğretmenler, kitaptaki etkinliklerin yetersiz olduğunu, buna dayalı olarak ek etkinliklere ihtiyaç duyduklarını ve fotokopilerle etkinlikleri desteklediklerini belirtmiştir. "Etkinlik özellikleri" alt temasını oluşturan eksik yönerge koduna ilişkin olan öğretmen görüşlerinin örnekleri aşağıda verilmiştir.

Bütün etkinlikler için geçerli olmasa da, bazen benim bile nasıl yapılacağını anlamakta zorlandığım etkinlikler oldu. Nasıl yapılacağı daha açık olabilirdi. Veya yönlendirmeler yapılabilirdi (Ö5).

Etkinlikleri tan anlamılla yeterli olduğunu söyleyemem çünkü yönergeler eksikti. Bazı etkinlikleri ben bile anlayamadım. Etkinliği nasıl yapacağımı anlamadım. Yönergeler eksik olduğu için (Ö3).

Eksik yönerge kodunda görüş belirten öğretmenler, kimi etkinliklerin nasıl yapılacağının açıkça belirtilmediğini belirtmiş̧tir. Bu belirsizliğin kafalarını karıştırdığını ve etkinliği anlamakta zorlandıklarını vurgulamışlardır. "Etkinlik özellikleri" alt temasını oluşturan aşamalııı koduna ilişkin olan öğretmen görüşünün örneği aşağıda verilmiştir.

Etkinliklerde belirli bir zorluk yok. Yani kolaydan zora gidecek biçimde sıralanmamış. Hep aynı seviyede ilerliyor (...). Bu etkinlikler sürecin başında çocuklar için en fazla 10 dakika sürerken, sürecin sonunda 2 dakikalarını almıyor. Ama sürecin başında da 40 dakika veriliyor bu etkinliğe, sonunda da yine 40 dakika veriliyor benzer bir etkinliğe. Yani kolaydan zora doğru bir sıralama yapılmamış (Ö4).

Aşamalılık koduna ilişkin görüş belirten öğretmen, etkinliklerin kolaydan zora, basitten karmaşığa göre sıralanmadığını belirtmiştir (Ö4). Bu durum, etkinliklerin içeriklerinin düzenlenmesinde sistematik bir yaklaşımın benimsenmediği biçiminde yorumlanabilir.

"Süre" temasına ilişkin alt temalar ve kodlar Şekil 3'te verilmiştir. Şekil 3'te görüldüğü gibi "Süre" temasını "Eski programı yetiştirme çabası" ve "Tamamlanmamış uygulamalar" alt temaları oluşturmuştur. "Eski programı yetiştirme çabası" alt temasını oluşturan hızlandırılmış uygulamalar koduna ilişkin olan öğretmen görüşlerinin örnekleri aşağıda verilmiş̧tir. 


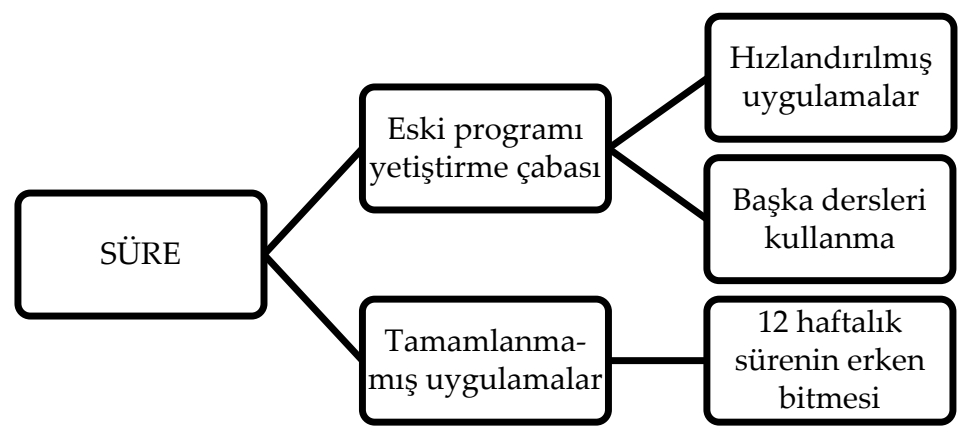

Şekil 3. "Süre" Temasına ilişkin Alt Temalar ve Kodlar.

Aralık ayına kadar uyum dönemi kitaplarını verdiler ama geçen senenin matematik kitabını da verdiler bize. Geçen senenin matematik kitabı nereden başlıyor, Eylül ayından başlıyor. Müfredat nerede bitiyor, Haziran ayında bitiyor. Biz nerede başlıyoruz, Aralık'ta başlıyoruz. Peki, biz bu müfredatı ne zaman yetiştireceğiz? Seneye ikinci sınıfa başladığımızda müfredatı tamamlamamış olarak 2. sınıfa geçtiğimizde nasıl olacak? Birinci sınıf müfredatını nasıl halledeceğiz? Bir sıkışıklık var. Bu nedenle hızlandık. Hızlanmak zorunda kaldık (Ö1).

Şimdi aslında 3 ayımızı çalmış gibi oluyorlar. Aynı şeyleri bekliyorlar. (...) Türkçe kitabına biz Şubat tatilinde geçiyorduk. Yani Ocak'ın sonuna kadar okuma yazma işi bitiyordu eskiden. Şubat tatilinden döndügüümüzde okuma parçalarına geçiyorduk Türkçede. Ama şimdi öyle bir şey olmayacak. Dolayısıyla oradaki okuma parçalarını yetiştiremeyeceğiz. Ama bir yandan da yetiştirmek zorundasınız. Çabuk çabuk vereceğiz yetişsin diye (Ö5).

"Eski programı yetiştirme çabası" alt temasını oluşturan başka dersleri kullanma koduna ilişkin olan öğretmen görüşünün örneği aşağıda verilmiştir.

Eski programa 3 Aralık'tan sonra başladık. Ama Serbest Etkinlikler derslerimiz var. Oyun ve fiziksel Etkinlikler derslerimiz var. O derslerde de o 3 ayda veremediğimiz, o eski programa göre veremediğimiz şeyleri de vermeye çalışıoruz (Ö5).

Başka dersleri kullanma koduna ilişkin görüş bildiren öğretmen (Ö3), yetiştirmedikleri konuları yetiştirebilmek için başka dersleri kullandıklarını söylemiştir. Özellikle o yaşlardaki öğrencilerin her türlü fiziksel ve sosyal gelişimi için şart olan Oyun ve Fiziksel Etkinlikler dersinde yetiştirilemeyen konuların işlenmesi oldukça düşündürücüdür. "Tamamlanmamış uygulamalar" alt temasını oluşturan 12 haftalık sürenin erken bitmesi koduna ilişkin olan öğretmen görüşlerinin örnekleri aşağıda verilmiştir.

Bu sene ilk geçildiği için çok uygulandığını zannetmiyorum. Ayrıca bir takip mekanizması da yoktu. "Bu çalışmaları yapacaksınız" dediler ve gittiler. Böyle olunca çoğu yapmadı. Yapan da hepsini yapmadı. 3 ay dolmadan bıraktılar. Ondan sonra "Aa iyi ki yapmamışız, okumaya geçmişiz" denildi. Yani ya herkes yapacaktı ya da kimse yapmayacaktı. Bende açıkçası geçtim harflere. (Ö6).

(...) Bir şekilde harf çalışmasına başlamak zorunda kaldı ki diğer okullarda da duyduğumuza göre zaten hiç kimse beklememiş. Biz Kasım'ın başında hemen hemen başlamış olduk. Hatta Kasım'dan önce de başladık yani. " $E$ " harfini, basit, ilk harfleri verdik. Şu anda normal harf seyrine başladık biz (Ö1).

12 haftalık sürenin erken bitmesi kodunda görüş bildiren öğretmen (Ö6), herhangi bir yaptırım olmadığı için çoğu öğretmenin uyum sürecini yarıda bırakıp, harfleri vermeye başladığını söylemiştir. Öteki öğretmen de (Ö1), çalışmaların bitmesine yaklaşık bir ay kala, çalışmaları bırakıp harflere geçtiğini ve eski programa göre olması gereken yeri yakaladığını belirtmiştir. Buna göre görüş bildiren 
öğretmenlerin bir kısmının uyum ve hazırlık çalışmalarını yarıda bırakıp eski uygulamalarına devam ettikleri söylenebilir.

\section{Öğretmenlerin Öğrencilere İlişkin Düşünceleri}

Araştırmada ikinci olarak yanıt aranan “Öğretmenlerin öğrencilere ilişkin düşünceleri nelerdir?” sorusuna yönelik olarak "Öğrenci" teması oluşturulmuştur. "Öğrenci" temasına ilişkin alt temalar ve kodlar Şekil 4'te verilmiştir. Şekil 4'te görüldüğü gibi "Öğrenci” temasını "Yaşadıkları sıkıntılar", "Seviye farkı" ve "Öğrenci özellikleri" alt temaları oluşturmuştur. "Yaşadıkları sıkıntılar" alt temasını oluşturan bilişsel koduna ilişkin olan öğretmen görüşlerinin örnekleri aşağıda verilmiştir.

Defterinizde yazdığınız son sayfayı açın dediğimde anlamıyorlar. Büyükler defterde yazdığı son sayfayı açıyor ancak küçükler anlamıyor. Defterin en son sayfasını açıyor. Sayfası bittiğinde benim satır bitti diyor. Sayfam bitti diyor. Yani arkaya geçeceğini düşünemiyor. Ve bunu sürekli sana gelip soruyor. Öğretmenim ne yapacağım diyor. Bu da sıkıntı oluyor (Ö10).

Bilişsel koduna ilişkin görüş bildiren öğretmen (Ö10), diğerlerine göre büyük olan öğrencilerle herhangi bir sıkıntı yaşamadığını belirtirken, küçük öğrencilerin söylenileni anlamada problem yaşadığını vurgulamıştır. Bu durum, öğrencinin öğretmeni anlamaması, yanlış anlaması ve sürekli yönlendirilmeyi beklemesini beraberinde getirmektedir. "Yaşadıkları sıkıntılar" alt temasını oluşturan duyuşsal koduna ilişkin olan öğretmen görüşlerinin örnekleri aşağıda verilmiştir.

(...) Şikâyet ediyor, bu arkadaşım yapamadı diyor. Yapamayan küçük çocuk büyük çocuğa yetişmek için uğraşıyor. Zorlanıyor, üzülüyor bu arada. Duygusal açıdan da bozuluyor çocuk. (...) (Ö1).

Küçük öğrencilerde bir ürkeklik, kendine güvensizlik ve karamsarlık oluştu. Öğretmenim yapamıyorum diye ağlayanlar, sıranın üzerine yatıp yapmak istemeyenler. (...). Velilerden duydum zaten evde ağlamışlar. "Anne bir görsen öbür çocuklar her şeyi yapabiliyor, her şeyi boyayabiliyor. Ben hiçbir şeyi yapamadım. "diyen çocuklar oluyormuş (Ö8).

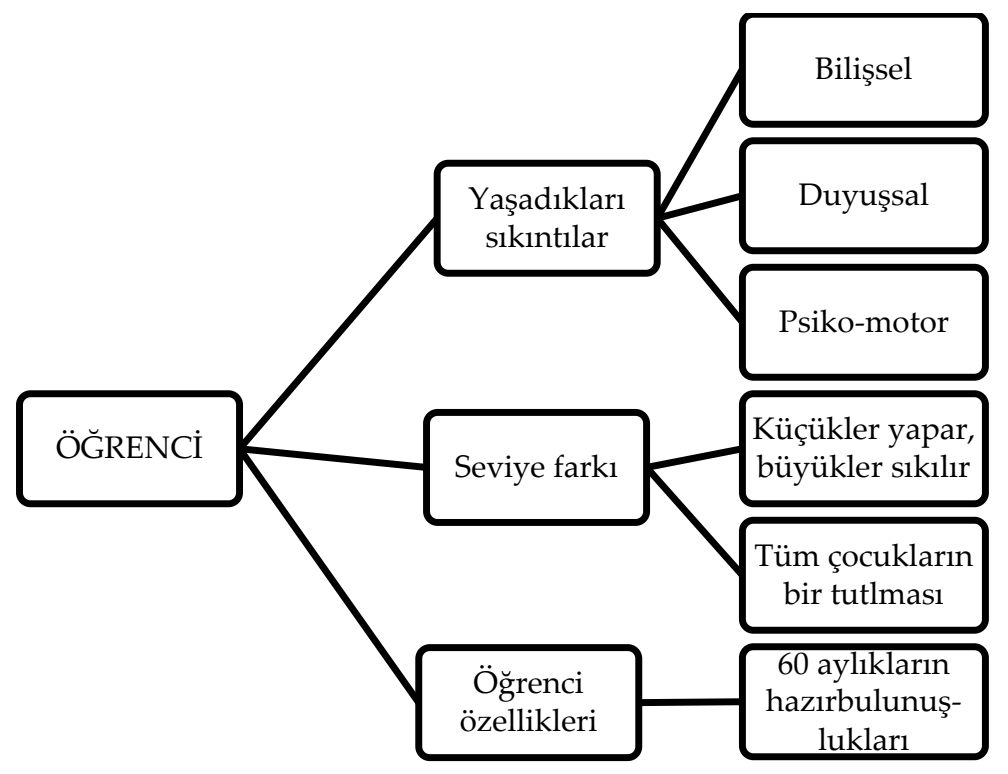

Şekil 4. "Öğrenci" Temasına iliş̧kin Alt Temalar ve Kodlar.

Duyuşsal koduna ilişkin görüş bildiren öğretmenler, kimi öğrencilerin büyük öğrenciler gibi yapmaya çalıştığı sırada zorlandığını (Ö1), kimilerinin de kendini yetersiz görüp görevi yapmaya isteksizlik ve 
kendine güvensizlik gösterdiğini belirtmişler. "Yaşadıkları sıkıntılar" alt temasını oluşturan psiko-motor koduna ilişkin olan öğretmen görüşlerinin örnekleri aşağıda verilmiştir.

Okulun ilk 15 günü hiç öğretmenler odasına uğramadan direk sınıfa gittim. Teneffüslerde dahi çıkmadım. Çocuk eline sabun dahi sıkamıyor. Tuvalete gidiyor, düğmesini ilikleyemiyor (...) (Ö8).

Tuvalet alışkanlığı hiç kazanmamış, kalem tutma alışkanlığı hiç olmayan çocuklar var. Çantasını açıp çantasından bir şeyler çıkarmada çok zorluk çekiyor... Böyle çocuklar olunca... Çok zorlandık.. Hem onlar, hem biz (Ö7).

Psiko-motor koduna ilişkin görüş bildiren öğretmenler, kas gelişimleri tamamlanmamış öğrencilerin öz-bakım becerileri gideremedikleri için sıkıntı yaşadıklarını belirtmişler. Ayrıca bu süreçte öğrencilere rehberlik ederken zorlandıklarını vurgulamışlar. "Seviye farkı" alt temasını oluşturan küçükler yapar, büyükler sıkılır koduna ilişkin olan öğretmen görüşlerinin örnekleri aşağıda verilmiştir.

Mesela bir matematik etkinliği var. "sayıp boyayın" diyor. Ama şimdi anasınıfına giden öğrenci iki yıldır bunu yapıyor zaten. iki yıldır çocuk boyuyor ama anasınıfına hiç gitmeyen öğrenci ilk defa böyle bir şeyle karşılaşıyor. O heyecanla başlıyor, diğeri sıkılıyor (Ö4).

Ana sınıfına gitmeyen öğrenciler için olumlu ama çocukların çoğu ana sınıfından geldiği için çok sıkıldılar. Sınıfta seviye farkı çok fazla oldu, ana sınıfından gelenler, "biz bunları yaptık öğretmenim, tekrar tekrar mı yapacağız", "biz artık ana sınıfı değiliz", "okula başladık artık biz derse geçmek istiyoruz" dediler ama ana sınıfına gitmeyenler ana sınıfına gitmediği için hoşlarına gitti çocukların (Ö7).

Küçükler yapar, büyükler sıkılır koduna ilişkin görüş belirten öğretmenler sınıftaki çocukların yaş farkının fazla olmasının sıkıntılara yol açtı̆ıını belirtmişler. Öğrenciler arasındaki bu seviye farkı, küçüklerin etkinlikleri benimsemesine, büyüklerin etkinliklerden sıkılmasına yol açtığını söylemişler. "Seviye farkı" alt temasını oluşturan tüm çocukların bir tutulması koduna ilişkin olan öğretmen görüşlerinin örnekleri aşağıda verilmiştir.

(...) Masanın yanındaki vazoyu yeşil renge boya diyor. Çocuk öğretmenim yeşil hangisi diyor ilk önce. Kitapta renklerin tanıtımı yok. Direk yeşile boya diyor. Onlar yeşili biliyormuş gibi hareket ediyor (Ö8).

Sınıfta 60 aylıkla 66 aylık ve 72 aylık çocukları ayırdım. Sınıfta ayırdım ama aynı tuvalete gidip aynı kantin sırasına giriyorlar. Ya bunları ayıracağız, komple bunları kendi başına okulları olacak. Hepsi aynı seviyede değil ki, bir tutulamazlar (Ö10).

Tüm çocukların bir tutulması koduna ilişkin bir öğretmen çocukların sanki okulöncesi eğitim almış gibi kabul edildiklerini belirtirken (Ö8) öteki öğretmen sınıf içinde öğrencilerini yaş gruplarına göre ayırdığını belirtmiştir (Ö10). "Öğrenci özellikleri” alt temasını oluşturan 60 aylıkların hazırbulunuşlukları koduna ilişkin olan öğretmen görüşlerinin örnekleri aşağıda verilmiştir.

Benim iki tane 2007 li öğrencim vardı. Gerçekten küçücük çocuk. Gerçekten hazır değiller. Çocuk küçük yani geliyor kedi gibi sokulmak istiyor. Bunlar da normal onun için. Dil gelişimi tamamlanmamış. Ona kadar sayamıyor. Rakamları tanımıyor.(...) (Ö3).

Sanki ilk defa birinci sınıf okutuyoruz Çünkü küçük çocuklarda hala bebeksi davranışlar var. Biz sırada oturmasını istiyoruz, işte gel dediğimizde gelmesini istiyoruz, hadi yapalım dediğimizde hep beraber yapmasını istiyoruz. Çocuk atıyor kalemi elinden, "Ben yapmayacağım." diyor. "Ben boyamak istiyorum." diyor. Çizgi çizeceğiz diyoruz. "Ben boyamak istiyorum, istemiyorum, küstüm." diyor. Yani 7 yaşındaki çocuk, 72 aylık,84 aylık çocuk bunu yapmaz. Küçük çocuklar bunu yapar(Ö1). 
60 aylıkların hazırbulunuşlukları koduna ilişkin görüş bildiren öğretmenler, çocukların okula başlamak için hazır olmadığını, bebeksi davranışlar sergilediğini, öğretmenin yönlendirmelerine karşılık vermediğini, sınıftaki öteki çocuklara ayak uyduramadığını belirtmişlerdir.

\section{Öğretmenlerin Uyum ve Hazırlık Çalışmalarının Öğrencileri Diğer Derslere Hazırlamasına iliş̧kin Düşünceleri}

Araştırmada üçüncü olarak yanıt aranan “Öğretmenlerin uyum ve hazırlık çalışmalarının öğrencileri diğer derslere hazırlamasına ilişkin düşünceleri nelerdir?” sorusuna yönelik olarak "Diğer derslere hazırlama" teması oluşturulmuştur. "Diğer derslere hazırlama" temasına ilişkin alt temalar ve kodlar Şekil 5'te verilmiştir.

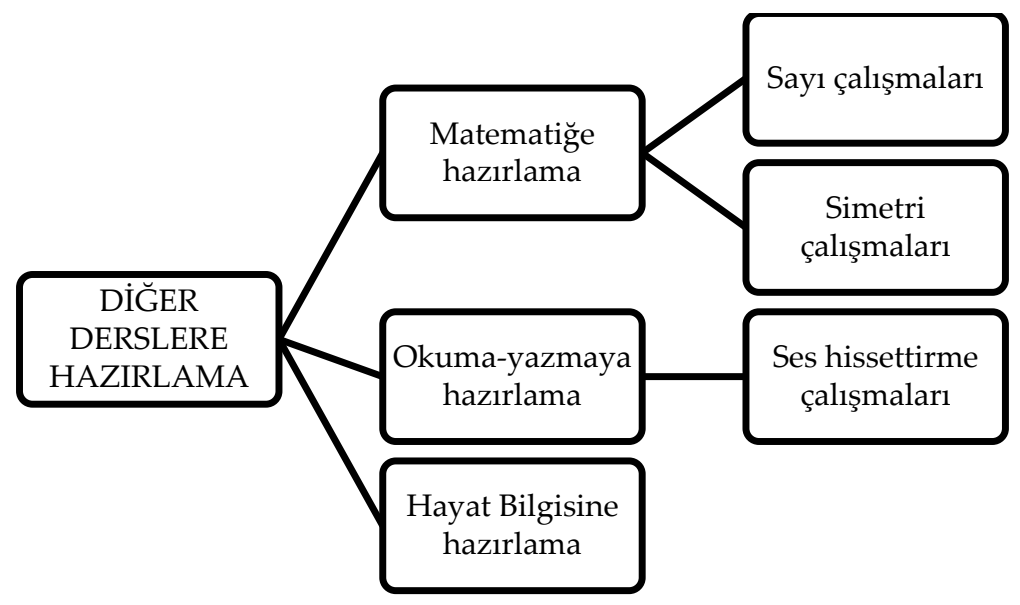

Şekil 5. "Diğer Derslere Hazırlama" Temasına ilişkin Alt Temalar ve Kodlar.

Şekil 5’te görüldüğü gibi "Diğer derslere hazırlama" temasını "Matematiğe hazırlama”, "Okumayazmaya hazırlama" ve "Hayat Bilgisine hazırlama" alt temaları oluşturmuştur. "Matematiğe hazırlama" alt temasını oluşturan sayı çalışmaları koduna ilişkin olan öğretmen görüşlerinin örnekleri aşağıda verilmiştir.

Matematik çok yetersizdi (...) yaşlarına göre ve çocukların geldiği seviyeye göre basitti. Sayılar 10'a kadar verilmiş. Yani sekizi vermiş ama iki sayfa vermiş iki sayfada da kocaman kocaman, birinde dört-beş tane sekiz yapmış üzerinden gidecek, diğer sayfada da sekiz tane noktacık koyacak o kadar yani (Ö7).

Matematikte sayıları vermeye çalışıyorlar uyum döneminde. Işste ilk 9 rakam işlenir. Ama bunu deftere yazdırmak, 2 rakamını yazmak gibi bir çalışma yok. Sayıyı belletme yani şeklini gösterme... Sezdirme işte 2’nin kaç olduğu, kaç tane nesneden oluştuğu gibi çalışmalar var (Ö1).

Sayı çalışmaları koduna ilişkin bir öğretmen, uyum sürecindeki Matematik konularını yetersiz bulduğunu, bu kapsamdaki etkinliklerin çocuklar için basit olduğunu söylemiştir (Ö7). Bir diğer öğretmen (Ö1), sayıları öğretme değil de sezdirme çalışmaları yaptıklarını vurgulamıştır. "Matematiğe hazırlama" alt temasını oluşturan simetri çalışmaları koduna ilişkin olan öğretmen görüşlerinin örnekleri aşağıda verilmiştir.

Etkinliklerin çoğunlukla çocukların seviyesine uygun olduğunu söyleyebilirim. Fakat bazıları da şaşırttı. Mesela simetri, yani 4. ve 5. sınıfta gördüğümüz simetri çalışmaları vardı. Bunlar daha basit olabilirdi (Ö8). 
Simetri çalışmaları koduna ilişkin görüş bildiren öğretmen, çoğu etkinliğin çocukların seviyesine uygun olduğunu söylemiş ancak, simetri çalışmalarının daha büyük çocukların seviyesine göre hazırlandığını, bu uyum dönemindeki çocuklara zor geldiğini vurgulamıştır. "Okuma-yazmaya hazırlama" alt temasını oluşturan ses hissettirme çalışmaları koduna ilişkin olan öğretmen görüşlerinin örnekleri aşağıda verilmiştir.

Sesi vermek yasak diyorlar, sadece duyacak diyorlar, sesi vermiyorsun. Bu defa da başta mı, sonda mı, ortada mı, bunu sezdirmeye çalışıyorsun. Örneğin "Talat'ta hangisinde $A$ var" "başta mı $A$ " "sonda mı $A$ " "ortada mı A" diye soruyorum çocuklara. Ama çocuk daha sesi tam kavrayamıyor, bilmiyor, A harfini görmeden söyleyemiyor. Sesi kavramadan olmuyor. Somut bir şey görmek istiyor, (Ö2).

(...) Işte başta olduğunda başını göster, ortada olduğunda karnını göster, sonda olduğunda bacaklarını göster... Bunlar oyun gibi geldi çocuklara, (...) şimdi yeni bir ses'i vermeye başladığımızda, diyelim ki 'o' sesini vereceğiz, 'o' sesini önce kavrattıktan sonra, "okul"un neresinde o var? Dediğiniz zaman hemen başını tutuyorlar (Ö7).

Ses hissettirme çalışmaları koduna ilişin görüş belirten bir öğretmen, çocukların somut olarak göremedikleri şeyi, kavrayamadıklarının üzerinde durmuştur (Ö2). Bir başka öğretmen ise ses hissettirme kapsamındaki etkinliklerin öğrenciler tarafından beğenildiğini, onlara oyun gibi geldiğini söylemiştir (Ö7). "Hayat Bilgisine hazırlama" alt temasına ilişkin olan öğretmen görüşleri aşağıda verilmiştir.

(...) Biz zaten günlük konuşmamızda kitap kullanmasak bile, günlük çalışmamızda Hayat Bilgisindeki konulardan hep bahsederiz. Milli bayramlardan, aile içi ilişkilerde, işte belirli gün ve haftalarda zaten değiniriz. Hayat Bilgisi kitabını kullanmasak bile yaparız bunu. Götürürüz yani. O anlamda hiçbir problem yok (Ö1).

(...) diyor ki yere çöp atarsak yerde tozlanır, biz de koşarak üstünden geçersek toz kalkar biz o tozu yutarsak hastalanırız. Çocuk bunu biliyor, basit geliyor. Ne anlatayım ben bu çocuğa yani. Yapacak bir şey yok. Başka etkinliğe geçsen aynı şeyi vereceksin zaten (Ö10).

"Hayat Bilgisine hazırlama" alt temasında görüş bildiren öğretmenlerden biri (Ö1), Hayat Bilgisi konularını anlatmak için kitaba gerek olmadığını, dersin konularını günlük yaşamdan aldığını ve zaten çocuklara sürekli günlük yaşamla ilgili bilgiler verdiğini anlatmış, uyum sürecindeki Hayat Bilgisi etkinliklerine değinmemiştir. Bir başka öğretmen ise (Ö10), kitaptaki etkinliklerin zaten öğrencilerin bildiği şeyleri içerdiğini ifade etmiştir.

\section{Öğretmenlerin Kendi Rollerine ilişkin Düşünceleri}

Araştırmada dördüncü olarak yanıt aranan "Uyum ve hazırlık çalışmaları kapsamında öğretmen rolleri nelerdir?" sorusuna yönelik olarak "Öğretmen" teması oluşturulmuştur. "Öğretmen" temasına ilişkin alt temalar ve kodlar Şekil 6’da verilmiştir.

Şekil 6'da görüldüğü gibi “Öğretmen” temasını "Sınıf içi uygulamalar", "Hizmet içi eğitim" ve "Yeterli öğretmen" alt temaları oluşturmuştur. "Sınıf içi uygulamalar" alt temasını oluşturan disiplin sorunu koduna ilişkin olan öğretmen görüşlerinin örnekleri aşağıda verilmiştir.

Gitmeyenler için iyi ama gidenler için sıkıcıydı. Onlar çabucak yapıp bitiriyor diğerler, yapamayanlar çok ağır ilerliyor. Bu şekilde sınıfta bir kargaşamız oldu. Bir taraf bitiriyor bir taraf daha yapacağız diye uğraşıyordu. Bayağı problemliydi (Ö6). 


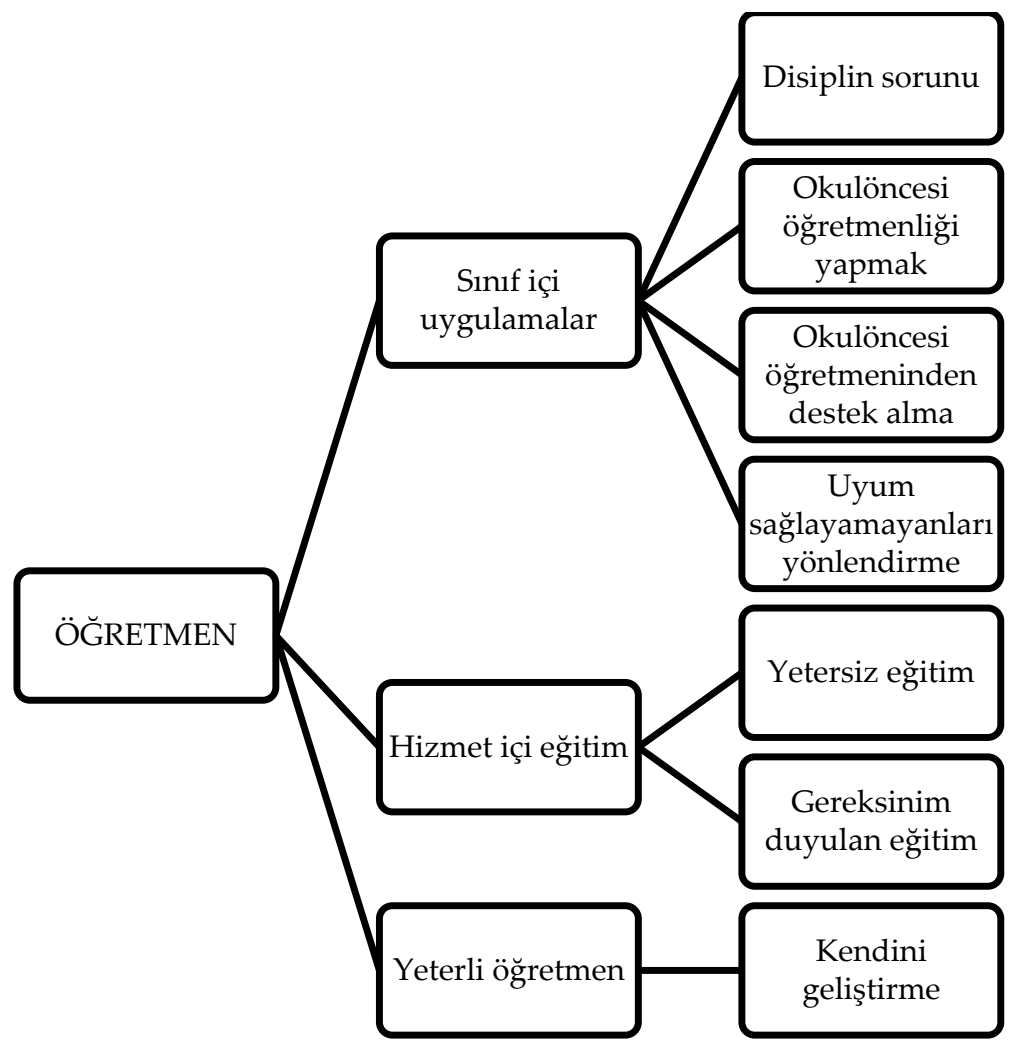

Şekil 6. "Öğretmen" Temasına iliş̧kin Alt Temalar ve Kodlar.

Kesme koordinasyon çalışmaları yapılırken, büyükler çok çabuk yapıyor. Bu sefer gürültü ortamı oluşuyor. Sıkıntı oluşuyor. Kendisine ilgiyi çekmek istiyor büyük yaş grubu. Böyle olunca tabi karmaşa oluşuyor (Ö2).

Disiplin sorunu koduna ilişkin görüş bildiren bir öğretmen (Ö6), okulöncesi eğitim alan çocuklarla almayan çocukların etkinlikleri yapma sürelerinin değiştiğini, buna bağlı olarak da, etkinliği erken bitirenlerin sıkıldığını ve sınıfın düzenini bozduğunu belirtmiştir. Öteki öğretmen ise (Ö2), etkinliği erken bitiren büyük öğrencilerin ilgi çekmek için gürültü ortamı oluşturduğundan bahsetmiştir. Her iki öğretmen de, sınıf yönetimini sağlayamadıklarına vurgu yapmışır. "Sınıf içi uygulamalar" alt temasını oluşturan okulöncesi öğretmenliği yapmak koduna ilişkin olan öğretmen görüşlerinin örnekleri aşağıda verilmiştir.

Kendimi bir okulöncesi öğretmeni gibi düşünmeye başladım bu süreçte. Okul öncesinin okuma yazmaya hazırlık etkinlikleri bu uyum etkinlikleri ile çok benziyor. (...) Onların sergiledikleri panolara bakıyorum. Bizim yaptığımız çalışmaların birebir benzer çalışmalar var. Yani sanki oradan esinlenilmiş. Şimdi ses öğretimine geçtiğimizde biraz daha kendimi o alana göre yeterli hissedeceğim. (...) Bir sınıf öğretmeni kesme, yapıştırma konusunda ne kadar üretken olabilir? Bunu tartışmak gerek (Ö4).

Ilk başlarda tereddüt ettim. Kitaplara şöyle bir bakınca, anasınıfı öğretmeni değiliz, bunlarla mı uğraşacağız dedim. Çünkü çok basit geldi konular. Ama sonra o çocukların da ihtiyaçlarının olduğunu görünce. Yani yapacak bir şey yoktu (Ö5).

Okulöncesi öğretmenliği yapmak koduna ilişkin olarak bir öğretmen (Ö4), bir sınıf öğretmeni olarak, okulöncesi kapsamına giren etkinlikleri etkili biçimde işleyebilmede ne kadar yeterli olabileceğini sorguladığını belirtmiştir. Ayrıca, uyum sürecindeki çalışmaların okulöncesi eğitiminde kullanılan 
çalışmalarda oldukça benzer olduğunu fark ettiğini söylemiştir. Bu konuda görüş bildiren bir başka öğretmen ise (Ö5), başlarda bocaladığını fakat sürecin içine girdikçe küçük öğrencilerin de okulöncesi kapsamındaki etkinliklere gereksinim duyduklarını fark ettiğini belirtmiştir. "Sınıf içi uygulamalar" alt temasını oluşturan okulöncesi öğretmeninden destek alma koduna ilişkin olan öğretmen görüşlerinin örnekleri aşağıda verilmiştir.

Yani destek aldık, tabi ki destek aldık, Özellikle ana sınıfı öğretmenlerimizden, okuldaki ana sınıfı öğretmenlerimizden çok destek aldık (...). Çocukların seviyelerine, uygun oyunları sorduk onlara. Önce kendimiz çıkardık, denedik. Kimi oyunları beraber sınıfta oynadık kapıyı kapatıp, "nasıl oluyordu bu oyun" falan diye, sözlerini falan unutmuşuz. Sonra çocuklara oynattık (Ö7).

Okulöncesi öğretmeninden destek alma koduna ilişkin görüş bildiren öğretmen, bir okulöncesi öğretmeninin yardımına ihtiyaç duyduğunu belirtmiştir. Okulöncesi öğretmeninin yönlendirmeleri doğrultusunda sürecin ilerlediğini söylemiştir. "Sınıf içi uygulamalar" alt temasını oluşturan uyum sağlayamayanları yönlendirme koduna ilişkin olan öğretmen görüşlerinin örnekleri aşağıda verilmiştir.

(...) Birinci sınıfa hazır olmadıkları için onları ana sınıfına yönlendirdim. Sağ olsunlar velilerde gönderdiler ve gayet memnunlar. Çünkü onlarda gördüler çocuklarının yapamadığını. Çocuk yapamayınca üzülüyordu, ağlıyordu kendini ezik hissediyordu. Arkadaşlarının yapabildiğini o yapamadığı için. Çocuk açısından anasınıfına gitmesi çok çok iyi olacaktı ve sanırım şuan iyiler (Ö5).

Rapor aldılar. Çünkü yapamadılar. Akşama kadar ağlıyor çocuk. Hiçbir şey yapmıyor. 15 gün denedik, olmadı. Veli de olmayacağını anladı zaten. Ne kalem alası var ne bir şey yapası var. Çocuk koyuyor masanın üstüne kafayı. Yani ne yaparsan yap, hediyeler verdim bak oğlum alışacaksın, yapacaksın ama bir çözüm olmadı. Bende veliyle görüşüp anasınıfına yazdırın dedim (Ö8).

Uyum sağlayamayanları yönlendirme koduna ilişkin görüş bildiren öğretmenler, çocukların uyum sağlayabilmeleri için elinden gelen çabayı gösterdiklerini belirtmişlerdir. Fakat çocukların hazırbulunuşluk düzeylerinin ilkokula başlamaya elvermemesi ve uyum sağlayamadıkları için psikolojilerinin bozulması nedeniyle velileri de ikna ederek, onları okulöncesi eğitime yönlendirdiklerini belirtmişlerdir. "Hizmet içi eğitim" alt temasını oluşturan yetersiz eğitim koduna ilişkin olan öğretmen görüşlerinin örnekleri aşağıda verilmiştir.

Uzaktan eğitim oldu. İçeriği genel olarak psikolojik davranışlar, öğrencinin durumları, sınıf içi yönetimi. Ama bu sınıf yönetimi de küçük çocuklara yönelik değildi. Büyük çocuklarda biz o sınıf yönetimini zaten genel olarak biliyorduk yani. Yaptığımız şeylerdi. Ama küçük çocuklara yönelik hiçbir çalışmamız yok. Çok yeterli olmadı açıkçası. Hizmet içi eğitimi ben yeterli bulmadım açıkçası. Ki bana kimse o yaş grubuna harfi nasıl göstereceğimi, çocukların kas gelişimini nasıl yapacağımı anlatmadı. Çok şey yani, akademik anlamda gördük (Ö1).

Sene sonunda bir haftalık bir çalışmaya gittik o kadar. Yani o da çok yararlı değildi bence. Çok açıklayıc değildi. Bu uyum süreciyle ilgili hiçbir eğitim verilmedi bize. Ama daha sonra bir daha birinci sınıfta şöyle şöyle yapılacak diye sadece programı uygulayacaksınız dediler bize o kadar (Ö6).

Yetersiz eğitim koduna ilişkin görüş bildiren bir öğretmen (Ö1), aldıkları eğitimin içeriğinden bahsetmiş ve küçük çocukların gereksinimlerine, özelliklerine ilişkin hiçbir bilgi verilmediğini belirtmiştir. Anlatılanları çok akademik olması bakımından eleştirmiştir. Bir diğer öğretmen ise (Ö6), sadece bir haftalık bir eğitim aldıklarını ve bu eğitimin içeriğinin uyum süreciyle ilgili olmadığını bu nedenle yetersiz bulduğunu belirtmiştir. "Hizmet içi eğitim" alt temasını oluşturan gereksinim duyulan eğitim koduna ilişkin olan öğretmen görüşlerinin örnekleri aşağıda verilmiştir. 
Birebir yüz yüze eğitim gerekiyor. Sınıf ortamında bir eğitim gerekiyor öğretmenlere. Uzaktan değil yani açıkçası. Ya orada bana çıkıp anlatan akademisyen yani bunun nasıl olduğunu bana birebir göstermesi gerekiyor. Böyle yapacaksınız, böyle yapacaksınız demekle olmuyor bu. Uzaktan olunca eğitim, bize de çok uzak oluyorlar (Ö1).

Gereksinim duyulan eğitim koduna ilişkin görüş bildiren öğretmen, verilen hizmet içi eğitimin nasıl olması gerektiğine vurgu yapmıştır. Uzaktan eğitimle gerçekleştirilen bir hizmet içi eğitimin yetersiz kaldığını, bu konudaki uzmanların öğretmenlerle bire bir etkileşim içerisinde olması gerektiğini belirtmiştir. "Yeterli öğretmen" alt temasını oluşturan kendini geliştirme koduna ilişkin olan öğretmen görüşlerinin örnekleri aşağıda verilmiştir.

Zorluk çekmedim. Araştırdım. Bilgisayarım da var kendim yaptım. Kendi çalışmalarımı uyguladım. Sınıf öğretmeni her şeyi becerebilir diye düşünüyorum. Zorlanma yaşamadım. Anasınıfı öğretmeninin yaptığını hayli hayli yaparız yani (Ö2).

Uzaktan eğitimle hizmet içi eğitim verdiler. Çok yararını göremedim onun ben ama kendim araştırma yaptım. Internetten ya da kitaplar okudum. Anasınıfına dönük. Okulöncesi eğitimle ilgili. Yaş farkına göre hazırladım kendimi (Ö5).

Kendini geliştirme koduna ilişkin bir öğretmen (Ö2), sınıf öğretmenin kendini geliştirdiği takdirde tüm zorlukların üstesinden gelebileceğini belirtmiş ve okulöncesi öğretmeninin yaptığından daha fazlasını yapabileceğini iddia etmiştir. Öteki öğretmen ise (Ö5), verdikleri uzaktan eğitimle hizmet içi eğitimi yetersiz bulduğunu belirterek, yaş farkına ilişkin araştırma yaparak sürece hazırlandığını söylemiştir.

\section{Öğretmenlerin Velilere ilişskin Düşünceleri}

Araştırmada beşinci olarak yanıt aranan "Öğretmenlerin birinci sınıf öğrenci velilerine ilişkin gözlemleri nelerdir?" sorusuna yönelik olarak "Veli" teması oluşturulmuştur. "Veli" temasına ilişkin alt temalar ve kodlar Şekil 7 'de verilmiştir.

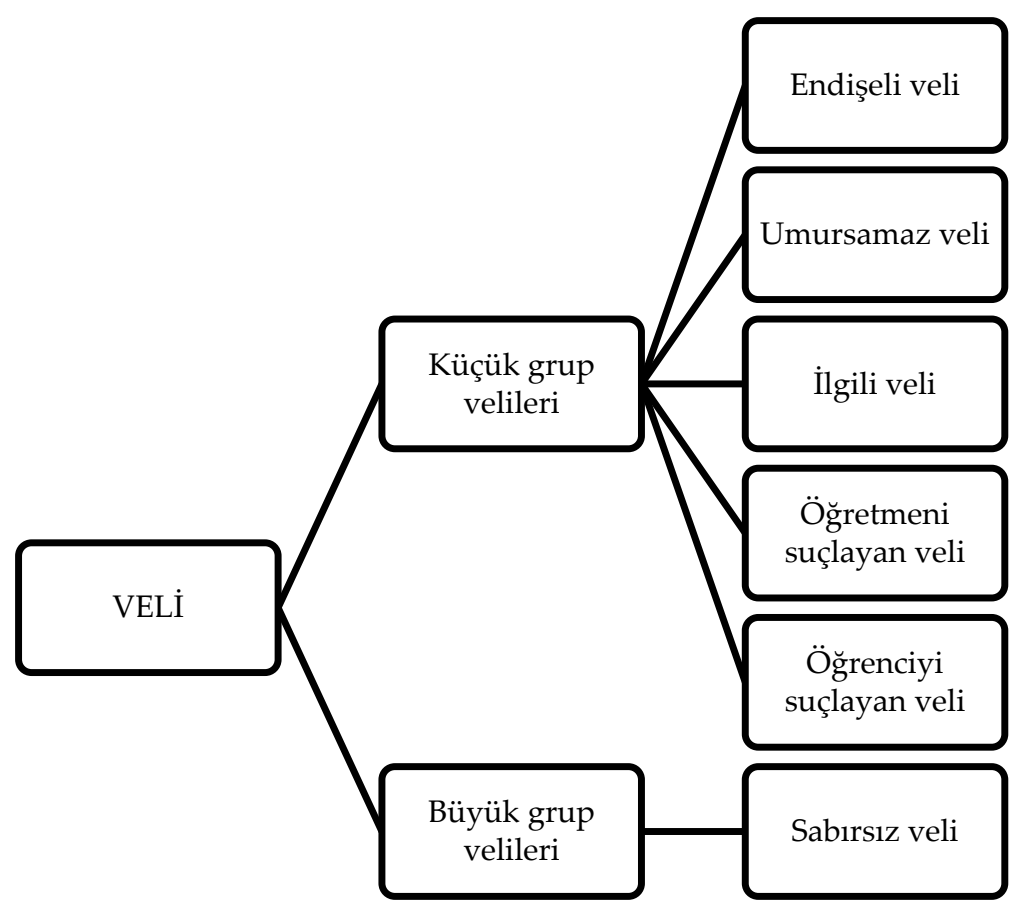

Şekil 7. "Veli" Temasına ilişkin Alt Temalar ve Kodlar. 
Şekil 7'de görüldüğü gibi "Veli" temasını "Küçük grup velileri" ve "Büyük grup velileri" alt temaları oluşturmuştur. "Küçük grup velileri" alt temasını oluşturan endişeli veli koduna ilişkin olan öğretmen görüşlerinin örnekleri aşağıda verilmiştir.

"Benim çocuğum beceremeyecek" "yapamayacak değil mi kızım?" "okuyamayacak değil mi oğlum?" diyen velilerim oldu tabi. Ben onlara hep şunu söyledim, "Çocuğunuzun zihinsel bir engeli yok. Ama geç ama erken yapacak. Merak etmeyin. Destek olun yeter" (Ö10).

Endişeli veli koduna ilişkin görüş bildiren öğretmen, küçük çocukların ailelerinin, çocuklarının küçük olmasından dolayı başarısız olacaklarını düşündüklerini ve kaygılandıklarını belirtmiştir. Bu süreçte ailelere telkinlerde bulunduğunu, onların kaygılarını azaltmayı amaçladığını dile getirmiştir. "Küçük grup velileri" alt temasını oluşturan umursamaz veli koduna ilişkin olan öğretmen görüşlerinin örnekleri aşağıda verilmiştir.

"Çocuğunuz çok küçük, kalem tutamıyor, oyunlara katılmıyor. Anasıııfı çağında. Çocuğunuzu takip edin. Yanındaki arkadaşının defteriyle çalışmalarını kontrol edin. Anasıııfına yönlendirelim" dememize rağmen umuruna getirmiyor. Anasınıfına vereceği 200 lira fazladan parayı düşünüyor. Cehalet bu yani, 200 lirayla çocuğunun geleceği değişiyor (Ö1).

Umursamaz veli koduna ilişkin görüş bildiren öğretmen, bu tip velilerin çocuğunun eğitimiyle ilgilenmediklerini, öğretmenin yönlendirmelerine kulak asmadıklarını belirtmiştir. "Küçük grup velileri" alt temasını oluşturan ilgili veli koduna ilişkin olan öğretmen görüşlerinin örnekleri aşağıda verilmiştir.

Teneffüse kadar bekliyor mesela. Işte örneğin, "Tuvaletin geldi mi?" diye soruyor. Çünkü 60 aylık çocuğu daha. Veli de hazır hissetmiyor çocuğunu. Kapıda, akşama kadar bekliyor. (...) Küçük öğrencilerin velileri okul çevresine daha yakınlar. İște hala oturup yemeğini ağzına veren gördüm ben (Ö4).

Illgili veli koduna ilişkin görüş bildiren öğretmen, velilerin kendi çocuklarının yapamayacaklarını bildikleri için sürekli etrafında bulunduklarını, ona yardım ettiklerini belirtmiştir. "Küçük grup velileri" alt temasını oluşturan öğretmeni suçlayan veli koduna ilişkin olan öğretmen görüşlerinin örnekleri aşağıda verilmiştir.

Küçük çocuklar geri kaldıkşa veliler bizi sıkıstırdı. Ötekiler önde gidiyor, biz niye arkada kaldık olayı çıktı. Veliler birbirini yarıştıııyor. Çok çalıştııı çok ödev veren, işte kaynak aldıran "aa iyi öğretmen" oluyor (Ö6).

Öğretmeni suçlayan veli koduna ilişkin görüş bildiren öğretmen, velilerinin çocuklarının geri kalmasını öğretmenlere bağladıklarını belirtmiştir. "Küçük grup velileri" alt temasını oluşturan öğrenciyi suçlayan veli koduna ilişkin olan öğretmen görüşlerinin örnekleri aşağıda verilmiştir.

Biz her ne kadar çocuğunuza kızmayın, yani yaptıktan sonra işte sen yaparsın, daha güzel yazabilirsin diye çocuğunuzu teşvik edin dememize rağmen, akşam eve vardığında vay sen niye yazamıyorsun, vay şu kalemi düzgün tut falan diye bağıııp çağırdıklarını biliyoruz. Sabah geldiğinde çocuk daha moralsiz geliyor. Akşam eve giderken moralsiz oluyor çocuk. Çünkü evde karşılaşacağı şeyi biliyor (Ö1).

Öğrenciyi suçlayan veli koduna ilişkin görüş bildiren öğretmen, velilerin çocuklarını zorladıklarından, onlara evde baskı uyguladıklarından bahsetmiştir. "Büyük grup velileri" alt temasını oluşturan sabırsız veli koduna ilişkin olan öğretmen görüşlerinin örnekleri aşağıda verilmiştir.

Büyük grup velileri hocam biz sıkıldık diyorlar. Onlardan da sızlanma geldi. Sıkıntılar yaşadılar. Çalışma böyle devam edecek. Uyum dönemi bu şekilde olacak dedik yani. Yapacak bir şey yok (Ö2). 
Özellikle büyük grupların velileri sabırsızlıkla ne zaman okuma yazmaya geçileceğini beklediler. Ben şunu söyledim onlara. 12 haftalık uyum sürecimiz var. Program böyle. Bunu yapmamız gerekiyor (Ö3).

Sabırsız veli koduna görüş bildiren öğretmenlerin ikisi de, velilerin bir an önce uyum sürecini bitirip okuma-yazma çalışmalarına geçmek istediklerini belirtmişlerdir. Onlara süreçten bahsettiklerini ve böyle devam etmesi gerektiği yönünde bilgi verdiklerini söylemişlerdir.

\section{Öğretmenlerin Çalışmalara ilişkin Önerileri}

Araştırmada altıncı olarak yanıt aranan "Öğretmenlerin çalışmalara ilişkin önerileri nelerdir?" sorusuna yönelik olarak "Öneriler" teması oluşturulmuştur. "Öneriler" temasına ilişkin alt temalar ve kodlar Şekil 8'de verilmiştir. Şekil 8'de görüldüğü gibi "Öneriler" temasını "Uygulamaya yönelik öneriler", "Süreye yönelik öneriler", "Öğrenciye yönelik öneriler" ve "Öğretmene yönelik öneriler" alt temaları oluşturmuştur. "Uygulamaya yönelik öneriler" alt temasını oluşturan öğretmenlere sorulmalı koduna ilişkin olan öğretmen görüşlerinin örnekleri aşağıda verilmiştir.

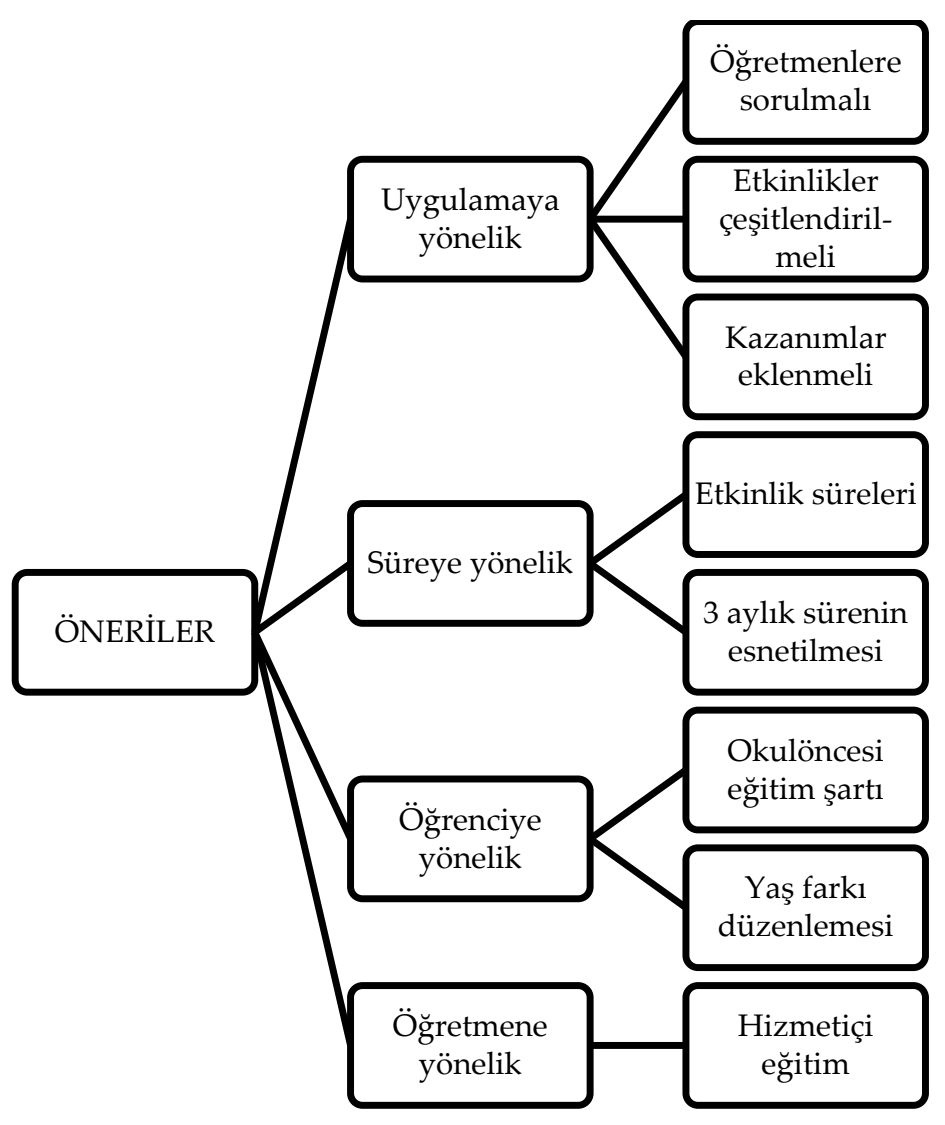

Şekil 8. "Öneriler" Temasına ilişkin Alt Temalar ve Kodlar.

Çocukların ne kadar sürede öğrenebileceklerini, nerede hata yapabileceklerini çok iyi biliyoruz ama kimse bize buna ilişkin fikir sormadı, anket yapmadı. Yani her şey için anket yapılır bizde. Ama bunu sormadılar. İşin içinde, yani hamurun içinde eli olan insanlara sormadılar maalesef. Biz de bunun sıkıntısını şimdi yaşıyoruz (Ö1).

Uşak gibi, Bilecik gibi, Bolu gibi birkaç tane küçük ile pilot çalışması yapılabilirdi. Aksaklıklar görülebilirdi. Oradaki öğretmen görüşleri alınabilirdi (Ö10). 
Öğretmenlere sorulmalı koduna ilişkin görüş bildiren öğretmenlerden biri (Ö1), öğretmenlere her şeyi sorduklarını fakat sormaları gereken en önemli şeyi sormadıklarını belirtmiştir. Öteki öğretmen ise (Ö10), çalışmanın uygulamaya konmasından önce pilot çalışmasının yapılması gerektiğini, bu kapsamda öğretmenlerden fikir alınarak aksaklıkların düzeltilebileceğini vurgulamıştır. "Uygulamaya yönelik öneriler" alt temasını oluşturan etkinlikler çeşitlendirilmeli koduna ilişkin olan öğretmen görüşlerinin örnekleri aşağıda verilmiştir.

Bence etkinlikler daha fazla olmalı. Çok az etkinlik var, yani kocaman bir kitap verilmiş bir de yardımcı kitabı var ama inanın içi boş. Daha farklı etkinliklerle desteklenebilirdi diye düşünüyorum, yetersiz bence. Yani onların verdiği etkinlik ile kavratmak istedikleri asla kavratılamaz (Ö7).

Etkinlikler çeşitlendirilmeli koduna ilişkin görüş belirten öğretmen, kitaptaki etkinlikleri yetersiz bulduğunu belirtmiştir. Kitapların etkinlik bakımından zenginleştirilmesi gerektiğini söylemiştir. "Uygulamaya yönelik öneriler" alt temasını oluşturan kazanımlar eklenmeli koduna ilişkin olan öğretmen görüşlerinin örnekleri aşağıda verilmiştir.

Hangi davranış kazandıracağımız da eklenebilirdi. Eskisi gibi kazanımlar yok. O da sıkıntı. Önceden olsa yaptığın çalışmaya göre, evet ben bu kazanımı veriyorum diye düşünüyorsun. Ama şimdi kazanımlar olmayınca biraz sıkıntı oldu (Ö3).

Siz öğretmen kılavuzu yapıyorsunuz. İçinde kazanım yok. Öğretmen ne kazandıracağını nasıl takip edecek? Buna yönelik düzenlemeye gidilebilir diye düşünüyorum (Ö4).

Kazanımlar eklenmeli koduna ilişkin görüş bildiren öğretmenlerden biri (Ö4), kılavuz kitabında kazanımların yer alması gerektiğini vurgulamış; bir diğeri (Ö3) eski programda kazanımların olmasına alıştıklarını ve buna ilişkin bir yöntem izlediklerini belirterek uyum sürecinde kazanımların olmamasının sıkıntısından bahsetmiştir. "Süreye yönelik öneriler" alt temasını oluşturan etkinlik süreleri koduna ilişkin olan öğretmen görüşlerinin örnekleri aşağıda verilmiştir.

40 veya 80 dakikalık bir süre veriyorlar. İşte o seksen dakikanın içerisine onu yapacağım diye planlıyorsun kendini. 15 dakikada her şey bitiyor. Aynı şeyi sürekli tekrar edince sıkılıyor çocuk. Zaten çok odaklayamıyorlar kendilerini. ilgileri çok çabuk dağılıyor (...) etkinlikler daha kısa olsa daha iyi olur (10).

Etkinlik süreleri koduna ilişkin görüş belirten öğretmen, öğrencilerin etkinlikleri verilen süreden daha çabuk bitirdiklerini ve daha sonra sıkıldıkları, bu nedenle etkinlik sürelerinin daha az olması gerektiğini belirtmiştir. "Süreye yönelik öneriler" alt temasını oluşturan 3 aylık sürenin esnetilmesi koduna ilişkin olan öğretmen görüşlerinin örnekleri aşağıda verilmiştir.

12 hafta çok uzun bir süre. Daha kısa olabilir. Şöyle söyleyeyim. Ben Kasımdan önce başladım. Harf çalışmalarına başladım. Uyum dönemini bitirdim çünkü çocuklar kas gelişimi başladı (Ö1).

3 aylık sürenin esnetilmesi koduna ilişkin görüş bildiren öğretmen, uyum sürecinin oldukça uzun zaman aldığını belirterek kendi sınıfındaki uygulamaları zamanından önce bitirdiğini söylemiştir. Bu bağlamda sürenin daha kısa olması gerektiğini vurgulamıştır. "Öğrenciye yönelik öneriler" alt temasını oluşturan okulöncesi eğitim şartı koduna ilişkin olan öğretmen görüşlerinin örnekleri aşağıda verilmiştir.

Bunu anasınıfına zorunlu tutup, anasınıfında bu uyumu sağlayıp, birinci sınıfa hazır olarak gelmelerini ben tercih ederim. Çünkü zorlandık yani, anasınıfına gitmeyenlerle çok zorlandık. Onlar hala arkadan takip ediyor diğerlerini. Daha zorlanarak devam ediyorlar. O süreyi kapatmak çok zor oluyor diğer çocuklarla. Şimdi bu sene çok karıştı. Kimisi anasınıfına gitmiş, kimisi gitmemiş. Kimisi küçük, kimisi gidecek yaşta buraya gelmiş. Ya o karışıklığı yaşadık yani. Öğretmen için de zor, veli için de zor, öğrenci için de zor. (Ö6). 
Okul öncesi eğitimi mutlaka olması gerekiyor. Bize kolaylık sağlıyor yani bu açıdan. En azından diğer çocuklar hani yan sayfaya geçiyoruz dediğimizde o işi becerebilen çocuk sorgusuz sualsiz orayı açıp bekleyebiliyor (Ö10).

Okulöncesi eğitim şartı koduna ilişkin görüş bildiren öğretmenlerden biri (Ö6), uyum sürecinin zorunlu okulöncesi eğitimle verilmesinden yana olduğundan bahsetmiş, öteki öğretmen (Ö6), okulöncesi eğitimim zorunlu olmasının sınıf öğretmenlerine sağladığı faydadan bahsetmiştir. "Öğrenciye yönelik öneriler" alt temasını oluşturan yaş farkı düzenlemesi koduna ilişkin olan öğretmen görüşlerinin örnekleri aşă̆ıda verilmiştir.

Küçük çocukla büyük çocuğun bir arada bulunması doğru değil. Ayrı sınıflarda olsalardı, yani o büyükler uyum sürecini yapmadan başlayabilirdi direk, küçükler de o uyum sürecini yaptıktan sonra başlayabilirdi. Arada biraz mesafe olurdu ama sonra onlar belki yetişebilirdi okuma yazma çalışmaları sona erdikten sonra (Ö7).

Yaş farkı düzenlemesi koduna ilişkin görüş bildiren öğretmen, uyum sürecinde büyük gruplar ve küçük grupları ayırmak gerektiğinden söz etmiştir. Her çocuğun kendi yaş grubuna yakın çocuklarla aynı sınıfa gitmesini daha doğru bulduğunu söylemiştir. "Öğretmene yönelik öneriler" alt temasını oluşturan hizmet içi eğitim koduna ilişkin olan öğretmen görüşlerinin örnekleri aşağıda verilmiştir.

Öğretmenlerin önce hizmet içi eğitime alınması lazım. Detaylı bir şekilde biz önce bir eğitileceğiz ki ondan sonra bildiklerimizi, gördüklerimizi çocuklara aktarabilelim (ö9).

Öğretmenlerin tekrar güzel bir eğitim alması şart. Uzaktan eğitim değil, yakından eğitim olmalı. Birebir eğitim olmalı (Ö1).

Hizmet içi eğitim koduna ilişkin görüş bildiren öğretmenlerden biri (Ö9), öğretmenlerin nitelikli bir hizmet içi eğitime tabi tutulmalarını önermiş, öteki öğretmen ise buna ek olarak gerçekleştirilecek olan hizmet içi eğitimin yüz yüze ortamlarda yapılması gerektiğini vurgulamışırı (Ö1).

\section{Sonuç, Tartışma ve Öneriler}

Sınıf öğretmenlerinin uyum ve hazırlık çalışmaları kapsamındaki görüşlerini ortaya koymayı amaçlayan bu araştırmada, araştırma sorularına dayalı olarak, etkinlik, süre, öğrenci, diğer derslere hazırlama, öğretmen, veli ve öneriler olmak üzere yedi tema oluşturulmuştur.

"Etkinlik" temasına ilişkin görüş bildiren öğretmenler, uyum ve hazırlık çalışmaları kapsamındaki etkinliklerin basit etkinliklerden oluştuğunu, sayıca az olduğu için ek etkinliklere gereksinim duyduklarını, etkinliklerin nasıl yapılacağına ilişkin açıklamaların eksik olduğunu söylemişlerdir. Etkinliklerin haftalara göre sıralanışında belli bir zorluk sırası izlenmediğini, etkinliklerin zorluk seviyelerinde aşamalı bir yükseliş olmadığını vurgulamışlardır. Demirel (2007), içeriğin düzenlenmesinde temel ilkeler arasında somuttan soyuta, basitten karmaşığa, kolaydan zora, bütünden parçaya ya da parçadan bütüne, günümüzden geçmişe, olaylardan kavrama ve genellemelere, yakın çevreden uzağa doğru yapılan bir sıralama olduğunu belirtmiştir. Bu bağlamda uyum ve hazırlık çalışmalarında içeriğin düzenlenmesinde sistematik bir yaklaşımın benimsenmediği söylenebilir.

"Süre" temasına ilişkin görüş bildiren öğretmenler, 3 aylık uyum süreci bittikten sonra kullanacakları ders kitaplarının bir önceki yıla ait olması ve Eylül ayında vermeleri gereken konuları Aralık ayında verecek olmalarından dolayı, eski programı yetiştirme çabası içerisinde olduklarını belirtmişlerdir. Bu kapsamda konuları hızlandııılmış olarak işleyeceklerini veya yetiştirebilmek için başka dersleri kullanabileceklerini ifade etmişlerdir. Bu noktada öğretmenlerin sınıfta zaman yönetimini sağlamada zorluk çektikleri görülmektedir. Etkili bir öğretim gerçekleştirmek için zamanın verimli kullanılması 
gereklidir (Ekici, 2009, s.101). Sınıfta zamanın tümü, eğitsel amaçlara yönelik etkinlikler için kullanılmalı, bunun için de sınıf süreçleri dikkatle planlanmalı ve zamana bağlanmalıdır (Başar, 1999). Aksüt (2008), sınıfta zaman yitiminin sıfırlanmasının olası olmadığını ancak en aza indirebilme çabasından söz edilebileceğinden bahsetmektedir. Bu durum, birinci sınıf öğretmenlerinin süreyi etkin kullanmada çok daha fazla çaba göstermeleri gerektiğini ortaya koymaktadır. Ayrıca bu temaya ilişkin görüş bildiren öğretmenlerden bazıları da 3 aylık uyum sürecini tamamlamadıklarını, bu süreci zaman kaybı olarak görüp harfleri vermeye başladıklarını ve sürecin gerçekleşip gerçekleşmemesine ilişkin herhangi bir denetimin yapılmadığını belirtmişlerdir. Bu noktada öğretmenlerin görüşlerinden hareketle her okulda farklı bir uygulama olduğu görülmektedir. Bu durum, okul yönetiminin tavrıyla ilişkilendirilebilir.

“Öğrenci” temasına ilişkin görüş bildiren öğretmenler öğrencilerin yaşadıkları bilişsel, duyuşsal ve psiko-motor sıkıntılardan bahsetmişlerdir. Bilişsel sıkıntılara ilişkin öğretmenler küçük öğrencilerin yönergeleri yerine getirmekte zorlandıklarını söylemişlerdir. Bu bağlamda küçük çocukların bilişsel gelişimlerinin, birinci sınıf öğretmeninin verdiği yönergeleri yerine getirecek düzeyde olmadığı söylenebilir. Duyuşsal sıkıntılara ilişkin öğretmenler küçük çocukların kendilerini büyük çocuklara göre yetersiz hissettiklerini ve duygusal açıdan çöküş gösterdiklerini belirtmişlerdir. Bu duygusal çöküşler, okula karşı olumsuz tutum geliştirme, kendine güvensizlik vb. gibi olumsuz durumları beraberinde getirebilir. Nitekim Bilir (2005), bir şeyi öğrenmeye hazır olmayan çocuğa, onu öğretmeye kalkmak sadece verimsiz olmakla kalmayacağını; aynı zamanda çocukta başarısızlığa, hayal kırıklığına ve aşağılık duygusunun oluşmasına yol açacağını belirtmiştir. Psiko-motor sıkıntılara ilişkin öğretmenler küçük çocukların kas gelişimlerini tamamlanmadığını, bu bağlamda kalem tutmada, tuvalet ihtiyacını gidermede sıkıntı yaşadıklarını belirtmişlerdir. Bu yaş grubundaki çocukların büyük kas gelişimi kemik kas gelişiminden daha ileride olduğundan koşma, atlama, tırmanma gibi büyük kaslarla ilgili becerilerde yetkin iken yazma, çizme, makasla kesme gibi küçük kaslarla ilgili becerilerde daha az başarılıdırlar (Senemoğlu, 2005). Bu görüşlere göre küçük öğrencilerin ilkokul birinci sınıfa başlamaya hazır olmadıkları söylenebilir. Dereli'ye (2012) göre, ilköğretime başarılı geçiş hazırbulunuşlukla mümkün olabilir. Bu da çocuğun duygusal, psikolojik fiziksel ve zihinsel gelişim açısından ilköğretime yerleşebilecek düzeye gelmesi ile sağlanabilir.

Öğrencilerin yaş gruplarının farklı olmasından kaynaklanan seviye farkından bahseden öğretmenler, çoğu etkinlikte küçüklerin heyecanla başladığını fakat büyüklerin sıkılarak baktığını gördüklerini belirtmişlerdir. Sınıfta iki farklı öğrenci grubu olması, bu öğrencilerin özelliklerinin ve gereksinimlerinin de farklı olması demektir. Dolayısıyla öğrenme-öğretme sürecinin etkili biçimde işleyişinde ve sınıf yönetiminin sağlanmasında aksaklıklar görülebilir. Bu noktada öğretmen etkili sınıf yönetimini sağlamalıdır. Etkili bir sınıf yönetimi, öğrencilerin ilgi, beklenti ve gereksinimlerini tanımayı gerektirir (Aydın, 2000, s.16). Bunun yanı sıra öğretmenler, farklı öğrencilerin aynı gibi düşünüldüğünden bahsetmişlerdir. Öğrencilerin ilgi, gereksinim ve yeteneklerinin eşdeğer kabul edildiğini söylemişler; sanki tüm çocukların okulöncesi eğitim almış gibi kabul edildiğini vurgulamışlardır. Bu noktada sorumluluğun öğretmene düştüğü söylenebilir. Öğretmen öğretme-öğrenme sürecini öğrencilerin bireysel ilgi ve gereksinimleri doğrultusunda planlamalı; her öğrencinin öğrenme hız, yetenek ve özelliğine cevap verebilmelidir. Bunun için öğrencilerle birebir ilgilenmeli, anında dönüt-düzeltmeler yaparak süreci iyileştirmelidir.

Sınıfındaki 60 aylık çocukların özelliklerinden bahseden öğretmenler, daha önceden alışkın olmadıkları öğrenci özellikleriyle karşılaştıklarından bahsetmişlerdir. Bu yaş grubundaki çocukların gelişim düzeyleri düşünüldüğünde, öğretmenlerin bahsettiği davranışları sergilemelerinin normal olduğu söylenebilir. Yeterli büyüme ve gelişme göstermeyen çocuklar, eğitim etkinliklerinde kullanacakları enerjiden yoksun olabilirler. Bu da akademik performanslarını düşürebilir ve başarısızlık duygusuna kapılmalarına neden olabilir (Bilgin, 2009). Öğretmen açısından bakıldığında ise, öğretmenlerin bu yaş grubundaki öğrenci özelliklerine alışkın olmamaları, aldıkları sınıf öğretmenliği eğitimi programıyla ilişkilidir. Lisans öğrenimleri sürecinde aldıkları derslerin içeriğini ilköğretim öğrencilerinin özelliklerinden oluşmaktayken, okuttukları öğrenciler okulöncesi dönemi öğrenci özelliklerini göstermektedir. Bunun 
yanı sıra, çalışmalara ilişkin etkili bir hizmet-içi eğitimden de yoksun kalan öğretmenlerin bu süreçte sıkıntı yaşamaları kaçınılmazdır.

Öğretmenlerin öğrencilere ilişkin görüşlerine bakıldığında, genel olarak sıkıntılar üzerine odaklandıkları, olumsuzlukları anlattıkları görülmektedir. Bu olumsuz görüşlerin temelinde öğrencilerin okula ve öğrenmeye hazır olmayışları yatmaktadır. Eğitim ya da okul süreci, çocuğun yaşamında çeşitli uyum sorunlarının yaşanabileceği önemli bir evredir (Topses, 2007, s.23). Yaşı ne olursa olsun, okula başlayan her çocuğun ilk başlarda kimi becerilerden yoksun olabileceği ve sıkıntı çekebileceği bir gerçektir. Bu nedenle okulun ilk günlerinde öğretmenin çocukların okula uyumu kolaylaştıracak önlemler alması gerekir. Ön öğrenmelerini harekete geçirebilen çocuklar uyum sürecini başarılı bir biçimde tamamlarken; hazırbulunuşluk seviyesi ilköğretime başlamaya uygun olmayan çocuklar uyum sürecinde sorunlar yaşayabilirler. Bu noktada çocukların hazırbulunuşluk seviyeleri, ilköğretime başlamalarında önemli bir role sahiptir. Dünya'nın farklı ülkelerinde çocuğun okul sorumluluklarını yerine getirebilecek zihinsel ve sosyal olgunluğa erişip erişemedikleri ile ilgili çalışmalar uzun yıllara dayanmaktadır. Pek çok ülkede çocuklara okula başlama aşamasında hazır bulunuşluk testleri uygulanmakta ve çocuğun çok yönlü olgunlaşmış olması önemsenmektedir (Kutluca Canbulat ve Canbulat, 2012). Ülkemizde de, okula başlama yaşına giren çocukların okula hazır olup olmadıklarını belirmek için çalışmalar yapılmalı, önlemler alınmalıdır. Bu kapsamda uzman akademisyenlerden oluşan bir kurul hazırlanabilir. Akademisyenlerin araştırma yapmaları için lojistik destek ve bütçe sağlanabilir.

"Diğer derslere hazırlama" temasına ilişkin görüş bildiren öğretmenler Matematik, Hayat Bilgisi dersinden ve okuma-yazmaya hazırlamadan bahsetmişlerdir. Öğretmenler, matematik dersinde sayı sezdirme çalışmaları yaparken kimi öğrencilerin zorlandıklarını belirtmişlerdir. Ayrıca kimi çalışmaların öğrencilere basit geldiğini, kimilerinin de seviyelerinin oldukça üstünde olduğunu belirtmişlerdir. Sınıftaki öğrencilerin yaş farklarının fazla olduğu düşünüldüğünde, etkinliklerin kimi öğrencilere basit kimilerine zor gelmesinin doğal olduğu söylenebilir. Öğretmenler, okuma-yazma çalışmalarına ilişkin sesleri öğretme değil de ses hissettirme çalışmaları yaptıklarını belirtmişlerdir. Ses hissettirme çalışmalarının öğrencilere çok soyut geldiğinden, bu nedenle kavramakta zorlandıklarından bahsetmişlerdir. Bu yaş grubundaki çocuklar işlem öncesi dönemdedir ve öğrenmek için somut örneklere gereksinim duymaktadırlar. İşlem öncesi dönemdeki çocuklar korunumu kavramakta güçlük çekmelerinin yanı sıra, soyut kavramları da anlayamazlar. Örneğin, hareket etmeyen nesneler onlar için "ölmüş", hareket ettiklerinde ise "canlanmış"tır (Erden ve Akman, 1995, s.57). Buna göre ses hissettirme çalışmalarının somutlaştırıması etkili olabilir. Yine, etkinliklerin öğrencilere oyun gibi geldiğinden ve bundan zevk aldıklarından bahsetmişlerdir. Nitekim Bilir'e (2005) göre, okul çağına giren çocuğun büyük bir hareket ve oyun ihtiyacı vardır. Bu bakımdan başlangıçta okul-içi faaliyetlere olabildiğince oyun havası verilmeli, yavaş yavaş, okul etkinliklerine geçmelidir. Hayat Bilgisi dersine hazırlamaya ilişkin öğretmen görüşlerine bakıldığında ise öğretmenlerin Hayat Bilgisi dersinin içeriğinin basit ve bilindik şeylerden oluştuğunu, bu nedenle kitaba gerek kalmadan öğrenilebileceğini vurguladıkları görülmektedir. Bu vurgu, uyum ve hazırlık çalışmalarındaki Hayat Bilgisi etkinliklerinden çok, sınıf öğretmenlerinin Hayat Bilgisi dersine olan genel algııını ortaya koymaktadır. Dündar'a (2002) göre, bu ders ile öğrencilere doğal ve toplumsal yaşama dair temel bilgiler verilmekte ve onların bu bilgileri günlük yaşamlarında kullanabilmeleri, yeni durumlara uyum sağlayabilmeleri için gerekli düşünsel beceriler kazandırılmaktadır. Böylelikle öğrenciler Hayat Bilgisi dersi ile hem kendilerini hem de çevrelerini daha iyi tanımaktadır. Bu görüş, Hayat Bilgisi dersinin ilköğretimdeki önemini ortaya koymaktadır. Bu nedenle öğretmenlerin, Hayat Bilgisi dersinin öneminin farkında olmalarına imkan verecek önlemler, bir an önce alınmalıdır.

"Öğretmen" temasına ilişkin görüş bildiren öğretmenler sınıf yönetimini sağlamada zorluk çektiklerinden bahsetmişlerdir. Yaşanan zorlukların, farklı öğrenci gruplarının ilgi, gereksinim ve özelliklerinin de farklı olmasından kaynaklandığı görülmektedir. Benzer yaş gruplarıın oluşturduğu bir sınıfta bile kimi zaman disiplin sıkıntıları yaşanabilmektedir. Yaş grupları farkının fazla olması, bu sıkıntıların yaşanma sıklığını da artırmaktadır. Bu süreçte ortaya çıkan karmaşanın giderilmesi için okul yönetimi tarafından bazı tedbirler alınmalıdır. Örneğin yaşı birbirine yakın olan öğrencileri aynı şubede 
toplamak etkili olabilir. Araştırmaya katılan öğretmenler, uyum süreci boyunca kendilerini okulöncesi öğretmeni gibi hissettiklerini, ne kadar yeterli olabileceklerini sorguladıklarını ve okulöncesi öğretmenlerinden yardım aldıklarını belirtmişlerdir. Öğretmenlerin mesleklerini gereği gibi yerine getirebilmeleri hizmet öncesinde ve hizmet içinde yeterli ve nitelikli bir eğitim almaları ile mümkündür (Gürkan, 2013). 1739 sayılı Milli Eğitim Temel Yasası'nda öğretmenlik mesleğine hazırlğın genel kültür, özel alan eğitimi ve pedagojik formasyon (öğretmenlik meslek bilgisi) ile sağlandığı belirtilmiş (Milli Eğitim Temel Yasası, 1973); öğretmen yetiştiren yükseköğretim kurumlarında bu alanlardaki dersler aracılığıyla öğretmen adaylarına belirli nitelikler kazandırmak amaçlanmıştır. Bu bağlamda sınıf öğretmeni ve okul öncesi öğretmeni yetiştiren kurumların öğretmen eğitimi programlarına bakıldığında, genel kültür ve öğretmenlik meslek bilgisi derslerinin benzerlik gösterdiği görülmektedir. Ancak, özel alan eğitimi dersleri birbirinden farklıdır. Bir okulöncesi öğretmeninin özel alan eğitimi kapsamında aldığı Çocuk Gelişimi ve Çocuk Beslenmesi derslerini, bir sınıf öğretmeni almamaktadır. Bu dersleri almayan bir öğretmenin, 60 aylık çocukların gereksinimlerine yanıt vermesi az da olsa mümkün olabilir fakat eksik olacaktır. Bu eksiklik çocuk için dezavantajlı olduğu gibi, öğretmen için de sıkıntılara yol açabilir. Öğretmen bu süreçte kendini yetersiz hissedecek, okul öncesi öğretmeninden yardım istemeye gerek duyacaktır. Bu açıdan bakıldığında sınıf öğretmenliği eğitimi alan öğretmenlerin okulöncesi yaş grubuna giren çocuklara öğretmenlik yapması bir takım olumsuzlukları beraberinde getirmektedir. Bu sorunun ortadan kalkması için ya yaş grupları yeniden düzenlenmelidir ya da yüksek öğretim kurumlarındaki sınıf öğretmenliği eğitim programı güncellenerek, programlara öğretmen adaylarının 60 aylık çocuğun gereksinimlerine karşılık vermelerini sağlayacak dersler eklenmelidir.

Araştırmaya katılan öğretmenler, uyum sağlayamayan öğrencileri okulöncesi eğitim kurumlarına yönlendirdiklerinden söz etmişlerdir. İyi bir öğretmen, çocuğa bir şey öğretmeye geçmeden önce, onun bunu öğrenmeye hazır olup olmadığını yoklamalıdır (Bilir, 2005). Öğretmenler, öğrenmeye hazır olmayan öğrencilerin durumlarını velilerle paylaşmalı ve sağılıkı bir karar vermelerinde yol gösterici olmalıdır.

Aldıkları hizmet içi eğitimin yetersiz olduğunu belirten öğretmenler, bu etkinliklerin asıl amacına hizmet etmediğini vurgulamışlar; uzaktan eğitim yerine yüz yüze eğitimi tercih ettiklerini belirtmişlerdir. Öğretmenlerin hizmet içi eğitiminin oldukça yetersiz olması, uyum sürecinin en büyük olumsuzluklarındandır. Onların gereksinim duydukları konuda alacakları etkili bir hizmet içi eğitim, hem karşılaştıkları problemlere çözüm önerileri üretmede onlara yol gösterici olacak hem de o konuya ilişkin bilgi sahibi olmalarına ve kendilerini yeterli görmelerine olanak verecektir. Kendinden ve bildiklerinden emin bir öğretmenin sınıfında etkili öğrenmenin gerçekleşmesi için bir engel yoktur. Bu bağlamda il Milli Eğitim Müdürlükleri, öğretmenlerin hizmetiçi eğitimlerinin iyileştirilmesine yönelik çalışmalar yapmalıdır. Araştırma kapsamında görüş bildiren öğretmenler arasında, kendini oldukça yeterli görenlerin ve okuyarak kendini geliştirdiğini belirtenlerin de olduğu görülmektedir. Öğretmenin kendini geliştirmesi, karşılaştığı sorunlarla baş edebilmede bazı çözüm noktaları araması ve araştırması da uyum sürecinin iyileştirilmesine büyük katkılar sağlayacaktır. Bunun için öğretmenlerin kendilerini geliştirmeleri ve bilgilerini yenilemelerini teşvik edici önemler alınmalıdır. Bu kapsamda öğretmenlerin lisansüstü eğitim almaları desteklenebilir.

"Veli" temasına ilişkin görüş bildiren öğretmenler küçük grup velilerinin kiminin endişeli, kiminin umursamaz, kiminin ilgili, kiminin de öğretmen veya öğrenciyi suçlayan veliler olduğundan bahsetmiştir. Bilindiği gibi çocukların okula ve öğrenmeye hazırlanmalarında, ailelerin birçok sorumluluğu vardır. Aileler, bu süreçte çocuklarıyla konuşmalı, onları dinlemeli ve rahatlatmalıdır. Aşırı koruyucu tutumları, okula ilişkin ön yargıları ve okuldan elde edilecek kazanımlara ilişkin yüksek beklentileri çocuğun okula uyumunu güçleştirecektir. Bu bakımdan aileler çocukta okul kaygısına neden olabilecek tutum ve davranışlardan kaçınmalı çocuklara okulla ilgili ön yargısız ve gerçekçi bilgiler vermeli, okulun ilk günlerinde olabildiğince sakin olmalı ve kaygı düzeylerini çocuklara yansıtmamalıdırlar (Yaşar, 2013). Bu noktada öğretmenin tutumu oldukça önemlidir. Öğretmen, veliye durumu anlatarak açıklama yapmalı, uyum süreci hakkında bilgi vermeli ve çocuğuna destek olması için veliyi bilinçlendirmelidir. 
“Öneriler” temasına ilişkin görüş bildiren öğretmenlerin önerilerini, uygulamaya, süreye, öğrenciye ve öğretmene yönelik olarak dile getirdikleri görülmektedir. Uygulamaya yönelik öneriler arasında çalışmanın uygulamaya konmadan önce pilot uygulamasının yapılarak öğretmenlerden görüş alınması, çalışma kitabındaki yetersiz etkinliklerin sayılarının arttırılarak çeşitlendirilmesi, öğretmenlere içeriği düzenlemede ve hedeften haberdar olmada yol gösterecek olan kazanımların belirlenmesi bulunmaktadır. Süreye yönelik olarak etkinlik sürelerinin azaltılmasını ve 12 haftalık uyum sürecinin esnetilmesini önerdikleri görülmektedir. Öğrenciye yönelik öneriler arasında okulöncesi eğitim şartının konması ve sınıfların küçük yaş gruplarından ve büyük yaş gruplarından oluşan çocukların bir arada öğrenim görmelerini sağlayacak biçimde şubelere ayrılması bulunmaktadır. Son olarak öğretmene yönelik öneriler öğretmenlerin sıkı ve etkili bir hizmetiçi eğitimden geçirilmeleri gerektiği yönündedir. Tüm bu öneriler, öğretmenlerin uyum sürecinde karşılaştıkları güçlüklere ilişkin çözüm önerileri niteliğinde algılanabilir ve ileri çalışmalarda öğretmen ve öğrenci gereksinimlerini belirleme aşamasında bu önerilerden yararlanılabilir.

Uyum süreci, çocukların okula ve öğrenmeye uyumunu kolaylaştıracak etkinlikleri kapsayan ciddi bir süreçtir. Çocuğun bu dönemde yaşadıkları, ileriki eğitim yaşamını olumlu veya olumsuz biçimde etkilemektedir. Bu bakımdan uyum sürecinin öğrenci gereksinimlerine yanıt vermesine özen gösterilmelidir. Araştırma bulgularına göre, uyum sürecinin en büyük eksikliklerinden biri; sürecin bir yönerge veya etkinlikler bütünü olmasından ileri gitmemesidir. Uyum ve hazırlık çalışmaları kapsamında programın temel öğelerine yer verilmediği görülmektedir. Yani uyum sürecinin ortaya konmasında bir program geliştirme çalışmasından bahsedilemez. Bu da uygulamada ciddi aksaklıkları beraberinde getirmiştir. Yine bir diğer eksiklik, farklı yaş gruplarının bir arada bulunması ve okulöncesi eğitim alan çocukla okulöncesi eğitim almayan çocuğun aynı sınıfta olmasıdır. Bu durum, sürecin işleyişini olumsuz yönde etkilemiştir. Söz konusu aksaklıkların giderilmesi ve etkili bir uyum sürecinin gerçekleştirilmesi için, değerlendirme ve gereksinim belirleme çalışmaları bir an önce yapılmalıdır. Hangi yaş grubundaki çocuğun neye gereksinim duyduğu belirlenmeli ve uyum sürecine gereksinim duyan çocuklar ile duymayan çocuklar birbirinden ayrılmalıdır. Bu çalışmalar yapılırken uyum süreciyle ilişkilendirilen tüm paydaşların etkin katılımı sağlanmalıdır. Bu konuda alanında uzman kişilerden destek alınmalıdır.

\section{Kaynakça}

Aksüt, M. (2008). Derslerle ilgili süre kullanımı. In Z. Kaya (Ed.), Sınıf yönetimi (pp.267-285). Ankara: Pegem Akademi.

Aydın, A. (2000). Sınıf yönetimi. İstanbul: Alfa Yayınları.

Başar, H. (1999). Sınıf yönetimi. İstanbul: Milli Eğitim Bakanlığı Yayınları.

Bilgin, M. (2009). Bedensel ve devinsel gelişim. In B. Yeşilyaprak (Ed.), Eğitim psikolojisi: Gelişimöğrenme-öğretim (pp.55-79). Ankara: Pegem Akademi.

Bilir, A. (2005). Illköğretim birinci sınıf öğrencilerinin özellikleri ve ilk okuma yazma öğretimi. Ankara Üniversitesi Eğitim Bilimleri Fakültesi Dergisi, 38 (1), 87-100.

Büyüköztürk, Ş., Kılıç Çakmak, E., Akgün, Ö. E., Karadeniz, Ş. \& Demirel, F. (2012). Bilimsel araştırma Yöntemleri. Ankara: Pegem Akademi.

Creswell, J. W. (2005). Educational research: Planning, conducting and evaluating quantitative and qualitative research. New Jersey: Pearson Education.

Demirel, Ö. (2007). Kuramdan uygulamaya eğitimde program geliştirme. Ankara: Pegema Yayıncılık.

Dereli, E. (2012). Okulöncesi öğretmenleri ile ilköğretim birinci sınıf öğretmenlerinin ilköğretime hazırlık süreci ile ilgili görüşlerinin karşılaştırılarak incelenmesi. Akademik Bakış Dergisi, 30, 1-20.

Dündar, Ş. (2002). İlköğretim okullarında hayat bilgisi dersi programlarının tarihsel gelişimi. Trakya Üniversitesi Bilimsel Araştırmalar Dergisi, 2 (11), 11-18.

Ekici, G. (2009). Öğretim yönetimi. In E. Karip (Ed.), Sınıf yönetimi (pp.69-111). Ankara: Pegem Akademi. 
Ekiz, D. (2009). Bilimsel araştırma yöntemleri. Ankara: Anı Yayıncılık.

Erden, M. \& Akman, Y. (1995). Eğitim psikolojisi: Gelişim-öğrenme-öğretme. Ankara: Arkadaş Yayınevi.

Erkan, S. \& Kırca, A. (2010). Okulöncesi eğitimin ilköğretim birinci sınıf öğrencilerinin okula hazır bulunuşluklarına etkisinin incelenmesi. Hacettepe Üniversitesi Eğitim Fakültesi Dergisi, 38, 94-106.

Gürkan, T. (2013). Okulöncesi eğitimi öğretmenlerinin eğitimi. In M. Sağlam (Ed.), Türk eğitim tarihi (pp.41-62). Eskişehir: Anadolu Üniversitesi Yayınları.

Kutluca Canbulat, A. N. \& Canbulat, M. (2012). Almanya'da okula alma uygulamaları ve Kiel Okula Alma Testinin Türkçe'ye uyarlanması. Ilköğretim Online, 11 (1), 1-17.

MEB (2012). Uyum ve hazırlık çalışmaları öğretmen kitabı: ilkokul 1. Sınıf. Retrieved October 12, 2012, from http://ttkb.meb.gov.tr/dosyalar/kitaplar/1sinif_ogretmenkitabi.pdf

Milli Eğitim Temel Yasası. (1973). Retrieved October 12, 2012, from http://mevzuat.meb.gov.tr/html/88.html

Senemoğlu, N. (2005). Gelişim öğrenme ve öğretim. Ankara: Gazi Kitabevi.

Topses, G. (2007). Öğrenci davranışlarını etkileyen psikolojik etmenler ve sorunlar. In L. Küçükahmet (Ed.), Sınıf yönetimi (pp.11-36). Ankara: Nobel Yayın Dağıtım.

Yaşar, Ş. (2013). Çocukları ilköğretime hazırlamada aile, okul, öğretmen ve çevreye düşen görev ve sorumluluklar. In Ş. Yaşar (Ed.), Illköğretime hazırlık ve ilköğretim programları (pp.123-139). Eskişehir: Anadolu Üniversitesi Yayınları.

Yıldırım, A. \& Şimşek, H. (2011). Sosyal bilimlerde nitel araştırma yöntemleri. Ankara: Seçkin Yayıncılık. 